STATE OF ILLINOIS

DWIGHT H. GREEN, Governor

DEPARTIIENT OF REGISTRATION AND EDUCATION

FRANK G. THOMPSON, DIRECTOR

DIVISION OF THE

NATURAL HISTORY SURVEY

THEODORE H. FRISON, CHIEF

Volume 21

BULLETIN

Article $S$

\title{
Duck Food Plants of the Illinois River Valley
}

FRANK C. BELLROSE, JR.

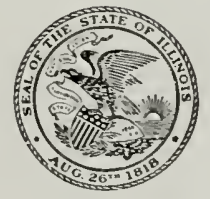

PRINTED BY AUTHORITY OF THE STATE OF ILLINOIS

URBANA, ILLINOIS

August 1941 
S T A T E OF I L L I N O I S

Dwight H. Green, Governor

DEPARTMENT OF REGISTRATION AND EDUCATION

Frank G. Thompson, Director

\section{BOARD OF NATURAL RESOURCES AND CONSERVATION}

Frank G. THOMpson, Chairman

William Trelease, D.Sc., Ll.D., Biology William A. Noyes, Ph.D., LL.D., Chem.D.,

Ezra J. Kraus, Ph.D., D.Sc., Forestry

D.Sc., Chemistry

L. R. Howson, B.S.C.E., C.E., Engineering Edson S. Bastin, Ph.D., Geology

Arthur Cutts Willard, D.Eng., LL.D.,

President of the University of Illinois

\section{NATURAL HISTORY SURVEY DIVISION Urbana, Illinois}

\section{SCIENTIFIC AND TECHNiCAL STAFF \\ Theodore H. Frison, Ph.D., Chief}

\section{Section of Economic Entomology}

W. P. FLINT, B.S., Chief Entomologist

C. C. Compton, Ph.D., Associate Entomologist

M. D. Farrar, Ph.D., Research Entomologist

J. H. Bigger, B.S., Associate Entomologist

S. C. Chander, B.S., Southern Field Entomologist

L. H. Shropshire, M.S., Northern Field Entomologist

WV. E. McC Auley, M.S., Assistant Entomologist

M. M. Petrakis, B.A., Entomological Assistant

C. J. Weinman, Ph.D., Research Fellow in Entomology

H. B. Petry, B.A., Research Fellow in Entomology

B. G. Berger, M.A., Research Fellow in Entomology

T. F. Winburn, M.S., Associate Entomologist (U.S.B.E.P.Q. and Commodity Credit Corporation, cooperating)

\section{Section of Insect Survey}

H. H. Ross, Ph.D., Systematic Entomologist

Carl O. Mohr, Ph.D., Associate Entomologist, Artist

B. D. Burks, Ph.D., Assistant Entomologist

G. T. Riegel, M.S., Entomological Assistant

Kathry M. Sommerman, M.S., Artist, Entomological Assistant

\section{Section of Forestry}

James E. Davis, M.F., Extension Forester

LeE E. Yeager, Ph.D., Forester

\section{Section of Aquatic Biology}

D. H. Thompson, Ph.D., Zoologist

George. W. Bennett, Ph.D., Limnologist

D. F. Hansen, Ph.D., Assistant Zoologist

Bruno Limbach, B.S., Zoological Assistant

Section of Game Research and Management

Ralph E. Yeatter, Ph.D., Game Specialist

\section{Section of Wildlife Experimental Areas}

Arthur S Hawkins, M.S., Game Technician

F. C. Bellrose, Jr., B.S., Assistant Game Technician

Jessop B. Low, Ph.D., Assistant Game Technician

Lyle K. Sowls, M.A., Assistant Game Technician

John M. Anderson, B.S., Funior Biologist

Cooperative Wildlife Restoration Program

(State Department of Conservation and U.S. Fish and Wildlife Service)

Harry G. Anderson, M.A., Funior Biologist

L. G. BRown, B.S., Funior Biologist.

R. E. Hesselschwerdt, B.A., Junior Biologist

Section of Applied Botany and Plant Pathology

L. R. TeHON, Ph.D., Botanist

D. B. Creager, Ph.D., Research Pathologist

J. C. Carter, Ph.D., Assistant Botanist

G. H. Boewe, M.S., Field Botanist

Section of Publications

James S. Ayars, B.S., Editor

Consultant: Herpetology, Howard K. Gloyd, Ph.D., Director of the Museum, Chicago Academy of Sciences 


\section{CONTENTS}

ACKNOWLEDGENTS.

IlliNois River HidrograPHY....... 23\%

Methods of StLdY ........

Effect of Variots Water Letels.... $2+5$

EFFECT OH FlOODS .............

EFFect of Drolght. . .......... 255

Effect of Water Flecteation ...... . . . . 256

Factors Infle encing Terbidity....... 257

Turbidity and Plant Ablidance....... 261

Water Depth and Plant Abendance.... 261

Other Factors in Plant Abundance........ 263

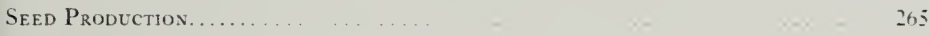

$\begin{array}{ll}\text { Important Duck Food Plants ........ } & 268\end{array}$

$\begin{array}{ll}\text { Plant Competition........ } & 269\end{array}$

Methods of Control.....

Natlral Propagatiox....... 272

Management Recommexditions.....

Tolerant Food Plants............. $\quad 275$

Methods of PLanting............ 276

SUMMARY. . . . . . . . . . . . . . 278

Literatere Cited............... 280

APPENDix.... .............. 280 


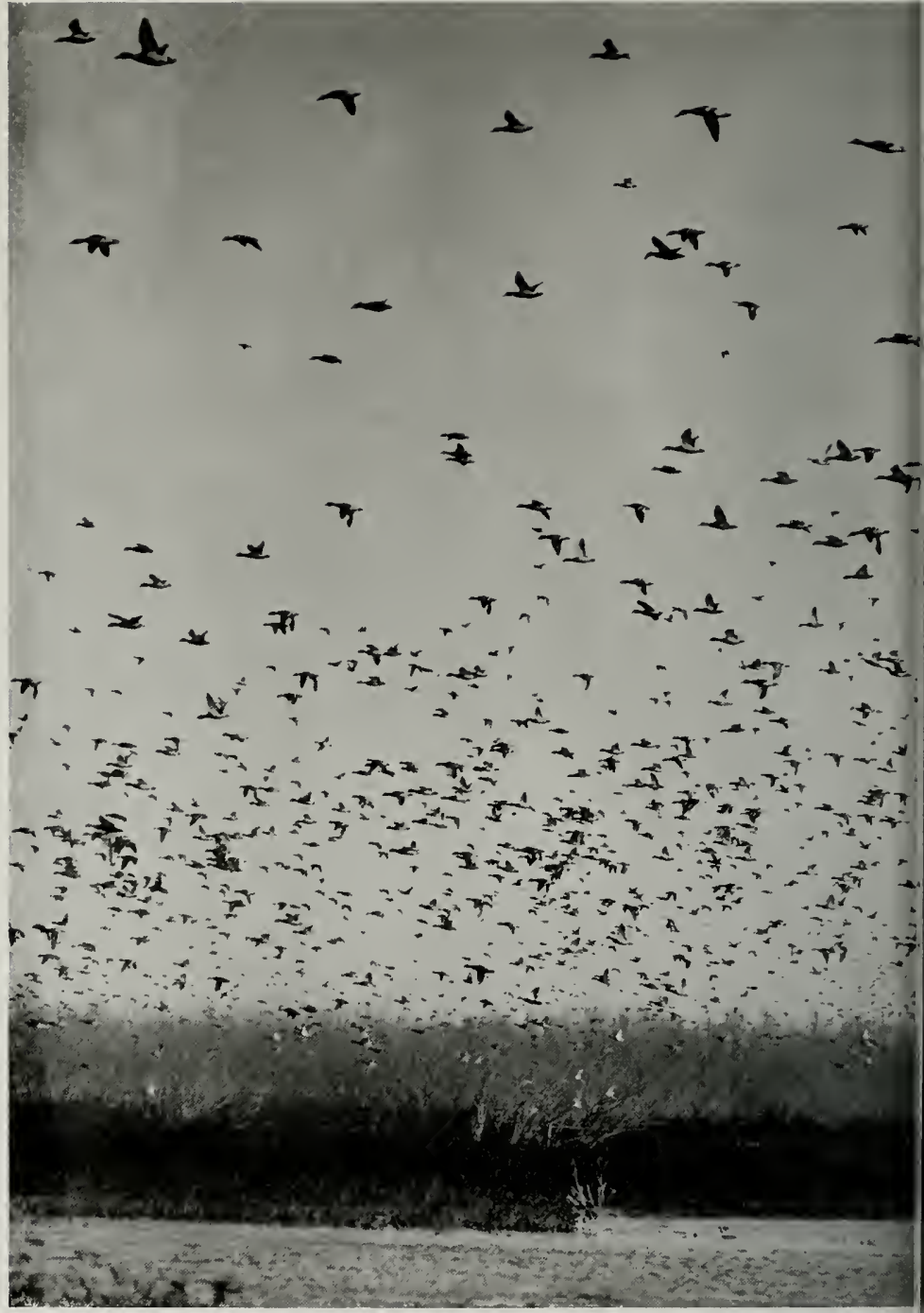

Duck flight at Lake Chautauqua, in the Illinois River valley a few miles above Havana. Some of the ducks, most of which are mallards, are dropping into the marsh smartweed beds. 


\title{
Duck Food Plants of the Illinois River Valley
}

\author{
FRANK C. BELLROSE, JR.
}

$\mathrm{E}^{\lambda}$ ACH year several million ducks pass through the lllinois River valley, scene of one of the greatest concentrations of migrating waterfowl in the United States. Over 90 per cent of the fall flight is made up of mallards, which have in recent vears found an abundant food resource in the mechanically picked corn fields lying adjacent to the bottomland lakes. Even though corn amounts to a considerable percentage of the plant diet of the mallard,* natural waterfowl feeding grounds still are important. Diving ducks and most baldpates, gadwalls, teal and pintails, as well as large numbers of mallards, congregate principally where natural food plants are abundant.

For the past 5 years the necessity for improvement of natural food beds in the Illinois River valley has been apparent. The large amount of money and effort being spent on artificial propagation of waterfowl food plants prompted the inauguration in 1937 of a study (Bellrose 1938) to determine the abundance and interrelation of aquatic plants and to discover optimum methods for management.

\section{Acknowledgments}

Mr. Arthur S. Hawkins of the Illinois Natural History Survey staff has helped in many ways with the present study. Mr. Francis M. Uhler, Associate Biologist, U. S. Fish and Wildlife Service, has given many valuable suggestions and sound criti-

* Harry G. Anderson. Junior Biologist, Illinois Natwral History Survey, State Department of Conservation and U.S. Fish and Wildlife Service, working on Federa Aid Project 2-R, examined 822 mallard gizzards in 1938 1,291 in 1939 and 428 in 1940 . Corn constituted 40 per cent by volume of the organic food in the 1938 gizzards. 54 per cent in the 1939 gizzards and 24.6 per cent in 54 per cent in the 1939 gizzards and 24.6 per cent in
the 1940 gizzards. The marked reduction in the per cent the 1940 gizzards. The marked reduction in the per cent in that year of moist soil duck food plants in the central part of the Illinois River valley. cisms. Messrs. Homer Bradley and Milferd Snith of the U.S. Fish and Wildlife Service have cooperated in studies made on the Lake Chautauqua National Wildlife Refuge.

\section{Illinois River Hydrography}

The lllinois River is formed by the junction of the Des Plaines and Kankakee rivers in eastern Grundy County, near Channahon, 111. From there, it flows 60 miles almost due west to Bureau, where it turns abruptly, flowing southwestward into the Mississippi River at Grafton. Its total length is about 270 miles, extending diagonally across the state from northeast to southwest. The major waterfowl habitat is located between Hennepin and Meredosia, a distance of about $1+0$ miles, fig. 1 .

Because its fall is slight-only 0.267 foot per mile over its length and 0.137 foot per mile from Utica to the mouth, a distance of 230 miles-the 1 llinois River is not able to carry its load and is in the process of building up its hottoms. Its immediate banks are higher than the surrounding bottomlands farther from the channel because in flood times the swift water of the channel drops its load where it meets the slower water of the flooded bottomlands.

The water level of the river and connected bottomland lakes fluctuates greatly with the season. The seasonal variation in water level over a 20 -year period is shown in fig. 2. This variation appears to have been very similar throughout the valley. It will be seen in fig. 2 that the general seasonal trend is for a spring rise to occur in February and high water to continue through May; for low water 
levels to occur during July, August and September; and for a small fall rise (25 per cent of the spring rise) to take place during October and November. Since the water generally fluctuates greatly during the plant growing season, it has a tremendous effect on aquatic life.

Because of drought, dredging, changes in the amount of water diverted from Lake Michigan, and creation of navigation dams on the Illinois River, the water levels of the river valley have undergone radical changes during the past few years. The yearly trend of water levels in the Illinois River, 1919-1939, is shown in fig. 3. It should be noted that, as a result of drought and a reduction in the amount of water diverted from Lake
Michigan, the level was considerably lower after 1930 than in the years just previous.

The seasonal fluctuations in water levels during 1938, 1939 and 1940, fig. 6, were abnormal in comparison with the seasonal trend represented in fig. 2. During the fall months of the years represented in fig. 6 , there was no appreciable, consistent rise in the water levels. Between Nov. 28 and Dec. 17, 19+0, a small rise occurred in the waters of the Illinois River at Havana. This was caused by the much publicized increase of about 9,000 cubic feet per second in diversion from Lake Michigan. Heavy precipitation resulted in high water throughout June and July, 1938, and from the middle of June

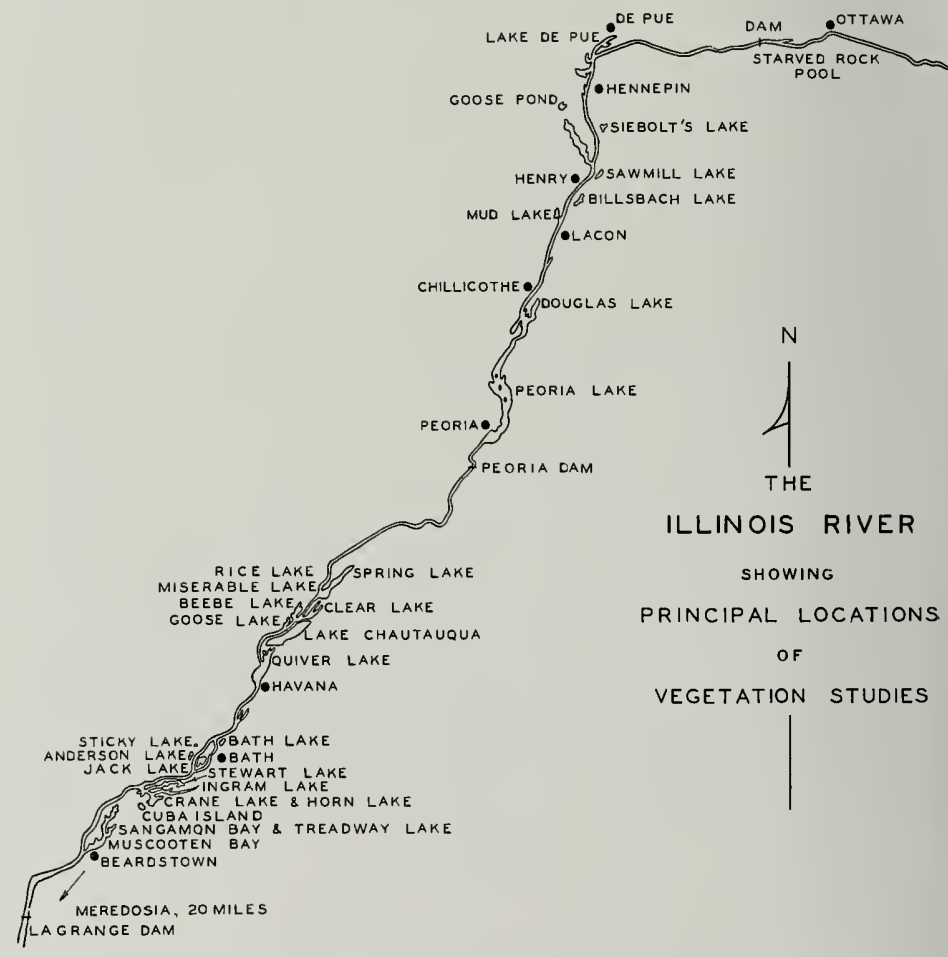

Fig. 1.- Principal concentration area of migratory waterfowl in the Illinois River valley. The map indicates the location of lakes involved in waterfowl food plant studies; also the location of dams and of cities and villages significant in this study. 


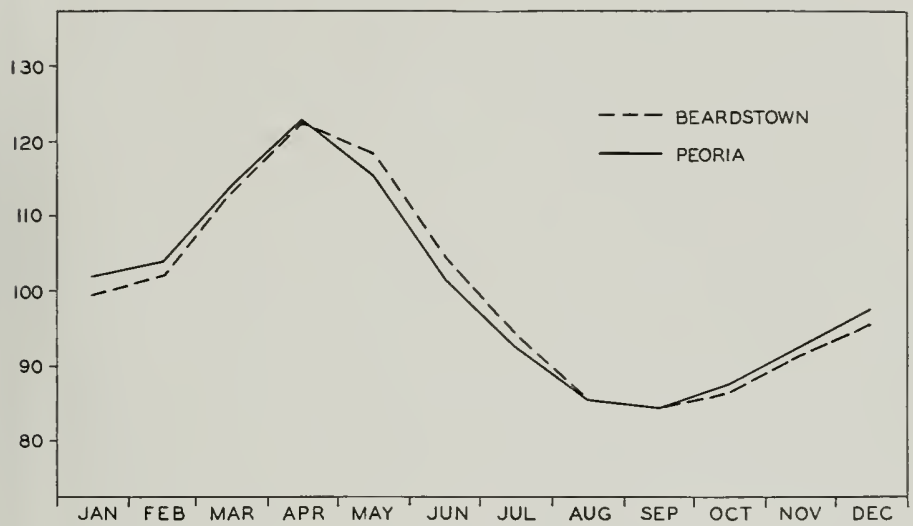

Fig. 2.-Index of seasonal variation in Hlinois River water levels over a 20-year period, 1920-39, at Peoria and Beardstown. Figures indicate per cent of variance from normal, which is 100 per cent.

to nearly the middle of July, 1939. In 1940 , there was a fluctuation of less than 2 feet of water at Havana, during May and June, and only relatively minor variations through the other months of the year.

Six navigation dams extend across the Illinois River system. Four dams, of the gate type, form narigation pools on the upper reaches of the Illinois and Des Plaines rivers. Two dams, of the wicket type, are located in the central section of the river. Only two lakes on the upper Illinois River are important waterfow] areas; they were formed by dams at
Starved Rock and Dresden lsland. In both these lakes, beds of sago and longleat pondweeds, wild celery, duck potato and other aquatic plants have in recent rears hecome established as a result of the reduction of turbidity, the reduction of current and the stabilization of water levels by the dams.

The two wicket dams, one situated a short distance below Peoria and the other, the La Grange dam, below Beardstown, are in the center of the Illinois River waterfowl habitat. They therefore play an important role in any waterfowl habi-

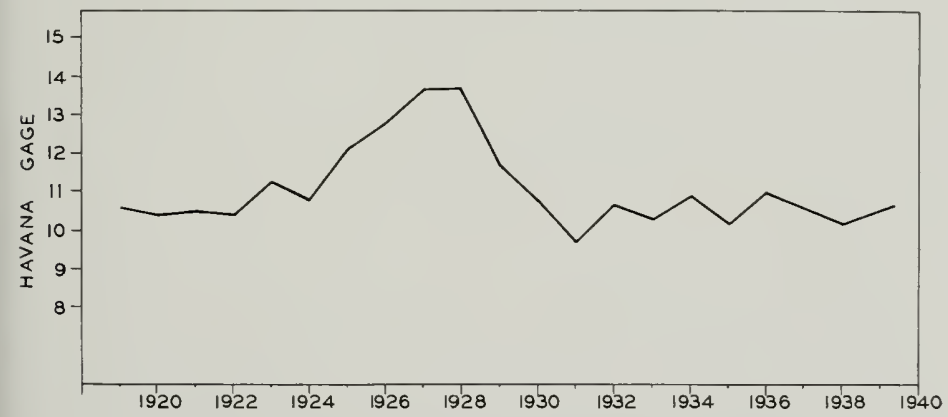

Fig. 3.-Trend in water levels of the Illinois River at Havana, 1919-39. The protile represents a moving average of three. Scale in feet. 
tat management program; they not only increase the size of certain waterfowl resting grounds, but they affect waterfowl food plants. The Peoria dam was placed in operation in December, 1938, and the La Grange or Beardstown dam on July 27, 1939. Figs. $t$ and 5 show a stabilization of water levels above the dams, except at flood stages, after each dam was placed in operation. Fig. 6 shows marked fluctuations of water levels in 1938 and 1939 at Havana, midway between the dams. The fact that fluctuations shown for 1940 at Havana were relatively small may be accounted for by the lack of heavy precipitation and the reduced, even flowage from
Lake Michigan, rather than by the dams.

Water of some of the fluviatile lakes does not fluctuate with that of the river, for dams and natural and artificial levees retain the water during drought periods. The best example of this condition is at the Lake Chautauqua National IVildlife Refuge, where artificial levees stabilize the water level, fig. 7 , except during periods of unusually high water, at which time the water rises over the spillways. From Feb. 14 to May 23, 1939, the water was above the 437.5-foot spillway elevation; it is obvious that during this period the water level inside the Chautauqua Refuge was practically identical with that of the river.

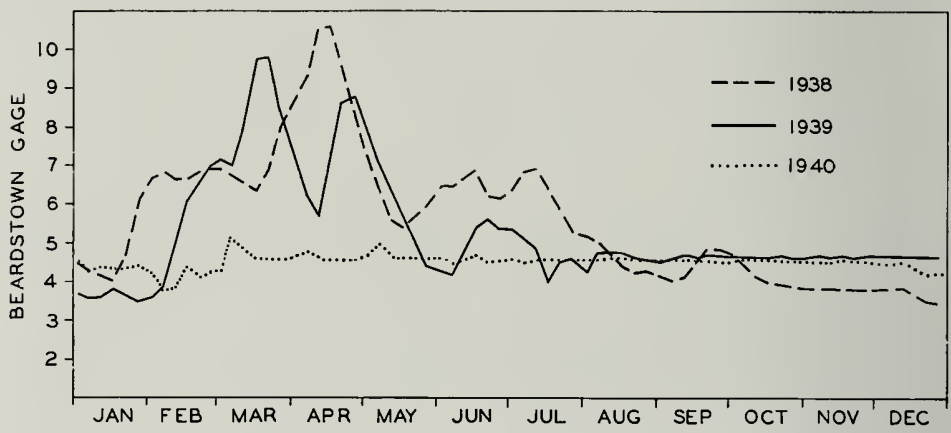

Fig. 4.-Seasonal fluctuation of Illinois River water levels at Beardstown, 1938, 1939 and 1940. Scale in feet. The decreased fluctuation in water levels, except at flood stages, in 1939 and 1940 , is a direct result of the La Grange dam, placed in operation July, 1939.

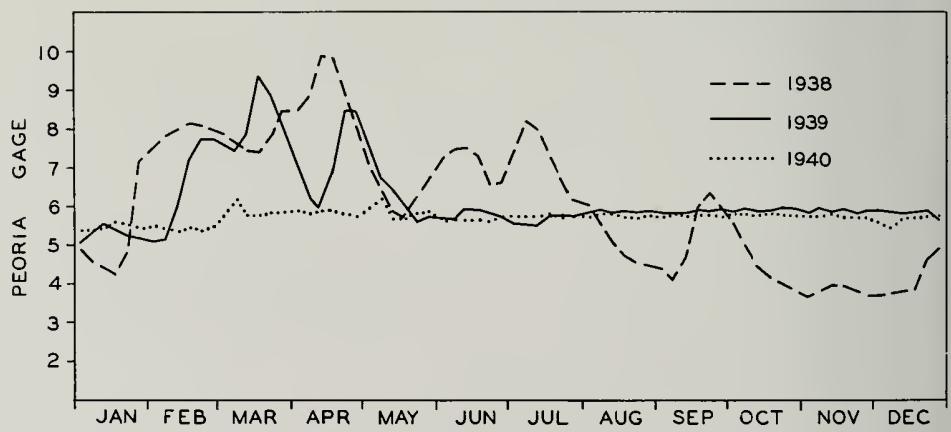

Fig. 5.- Seasonal fluctuation of Illinois River water levels at Peoria, 1938, 1939 and 1940. Scale in feet. The decreased fluctuation in water levels, except at flood stages, 1939 and 1940 , is a direct result of the Peoria dam, placed in operation December, 1938. 


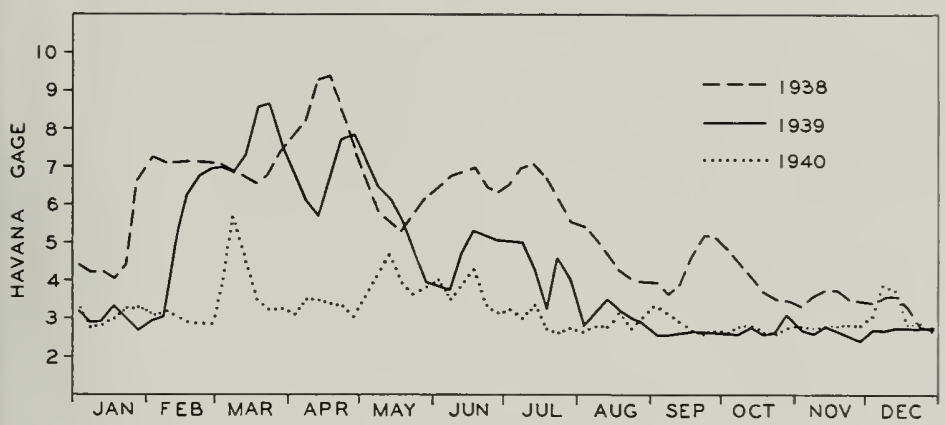

Fig. 6. - Seasonal fluctuations of Illinois River water levels at Havana, 1938, 1939 and 1940. Scale in feet. The river levels at Havana, midway between the La Grange and Peoria dams, apparently were little affected by these dams.

On either side of the river channel, from De Pue to Meredosia, numerous fluviatile lakes, ranging in size from 60 to 6,500 acres, dot the hottomlands, fig. 1 . Together these lakes form at low stage about 56,000 acres of water surface. while the river channel covers an additional 15,000 acres. In relation to regetation, lakes in the Illinois River valley may readily be grouped under three major types: (1) those with stable waters, except during flood stages; (2) those with fairly stable water levels, in which the water is high during flood times but is more or less retained during drought periods; and (3) those with widely fluctuating water levels, in which the water rises and falls with that of the river. The lakes of the last type usually have a wide entrance connecting the lower end of the lake with the river, while the land separating lake from river is low and flat, fig. 8 .

Prior to 1940 , lakes with stabilized water levels covered approximately 5.680 acres between Ottawa and Meredosia. These included the Staried Rock Pool, formed by a navigation dam on the Illinois River below Ottawa; the remnant of Spring Lake, inclosed by levees within the Spring Lake Drainage District near Banner; and Lake Chautauqua, an abandoned drainage district above Havana.

Prior to $19+0$, lakes with semistabilized water levels covered about 7,920 acres ad-

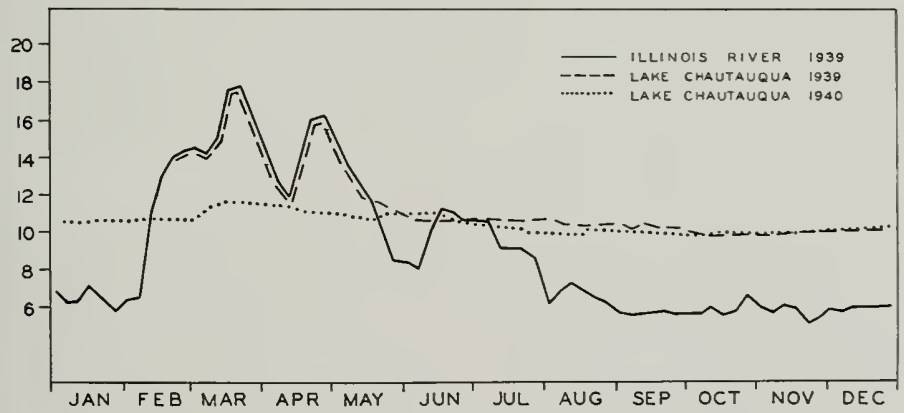

Fig. 7. Water levels, in feet, of the Illinois River in 1939 and of Lake Chautauqua in 1939 and 1940 . While water levels of the river fluctuate considerably, a stabilized water level is maintained in Lake Chautauqua except during flood periods such as occurred in the spring of 1939. 
jacent to the Illinois River. These lakes wine, Sawmill, Siebolt's and Billsbach, were Douglas, near Chillicothe; Rice, near Henry; Mud and Wightman's, near Beebe and Goose, near Banner; Cuba Is- Sparland; Upper and Lower Peoria, above

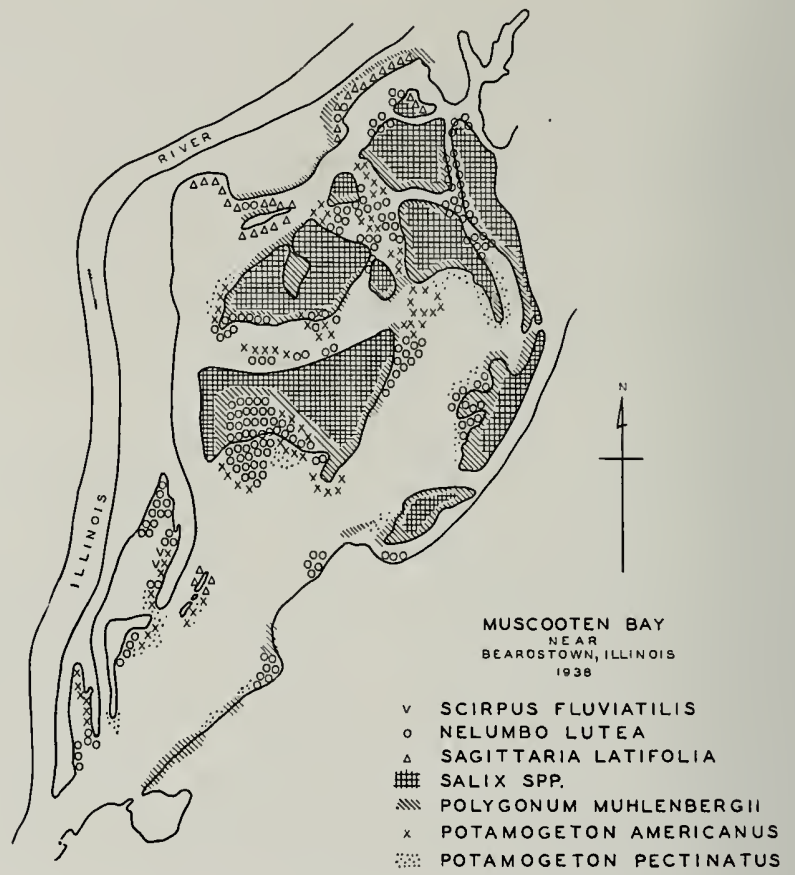

Fig. 8.-Vegetation map of Muscooten Bay, showing location of principal duck food bed. 1938. Muscooten Bay in 1938 had a scarcity of waterfowl food plants because of fluctuating water levels and high turbidity. A few patches of longleaf pondweed (Potamogeton americanus) occurred scattered among the islands of willow (Salix spp.), which protected them from the wind and thereby reduced the turbidity. Note that American lotus (Nelumbolutea) and marsh smartweed (Polygonum Muhlenbergii) were the two most common waterfowl food plants. However, many beds of marsh smartweed failed to produce seed because by the time of flowering the water had receded from the beds. As shown on the map a few beds of duck potato (Sagittaria latifolia) occurred despite the fluctuating water levels.

land, near Chandlerville; and Jack* and Anderson, near Sheldons Grove.

Prior to 1940 , lakes with fluctuating water levels greatly predominated in area throughout the valley. This type covered about 43,000 acres and included the following lakes; Lake De Pue, Spring Lake and Goose Pond, near Bureau; Senach-

*Regarded as a fluctuating lake in 1938; further observation in 1940 showed it belonged to the semistabilized type.
Peoria ; Clear and Quiver, above Havana; Muscooten Bay, Treadway Lake, Sangamon Bay, Crane, Ingram and Stewart lakes, above Beardstown; and Meredosia Bay, above Meredosia. Upper and Lower Peoria lakes were then, and are, merely broad expanses of the river.

In 1940, because of the absence of spring floods and because of stabilization of water levels by the Peoria and $\mathrm{La}$ Grange dams, the character of many lakes 
changed, with a resulting change in waterfowl food plants.

Hydrographically, Douglas Lake changed from the semistabilized to the stabilized type; Upper and Lower Peoria lakes, Mud and Wightman's lakes and Muscooten Bay from the fluctuating to the stabilized type; Goose Pond and Senachwine, Sawmill, Siebolt's, Billsbach and Treadway lakes changed from the fluctuating type to the semistabilized type of lake.

\section{Methods of Study}

During the summer and fall of 1937. a general survey was made of the regetation of certain lakes along the lllinois River (Bellrose 1938). In 1938, the scope of the study was broadened to include ascertaining the abundance of aquatic plants. Maps showing the area covered by various plant beds were constructed and a planimeter was then used to measure the area covered by each important plant spe-

Table 1.-Abundance of duck food piants in Class I lakes of the Illinois River valley-lakes with stable water levels. Figures in acres.

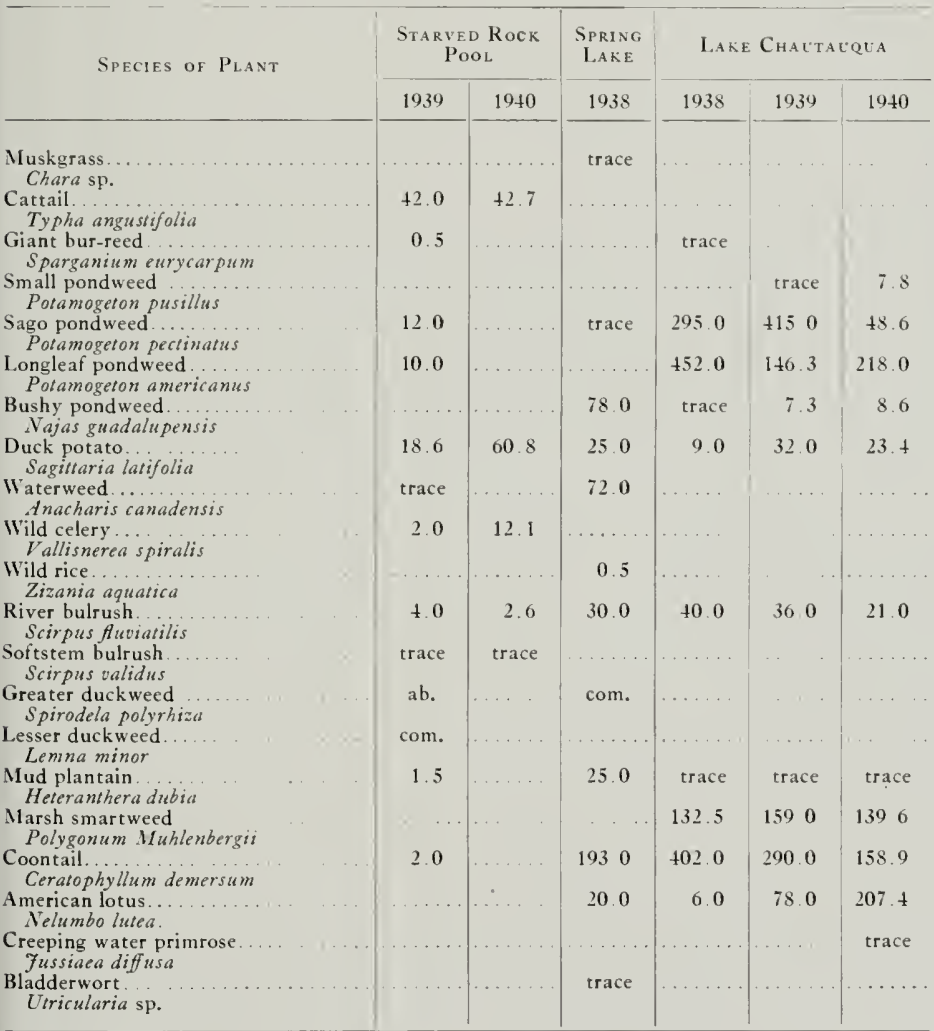

Note: $a b .=$ abundant $;$ com. $=$ common 


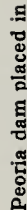

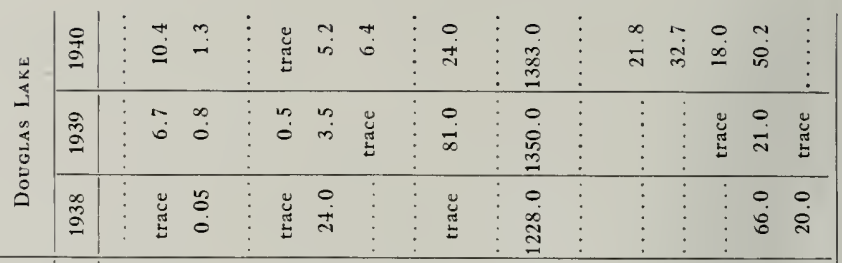

:

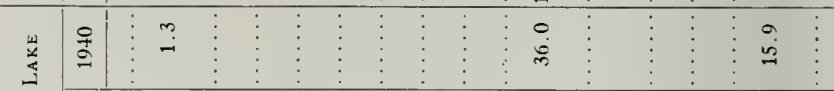

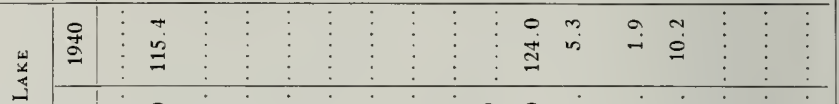

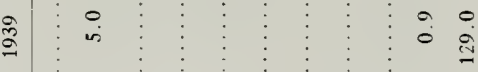

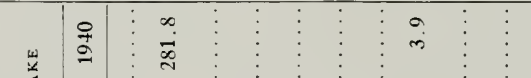




\begin{tabular}{|c|c|c|c|}
\hline 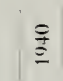 & @ & $\bar{z}$ & $\begin{array}{l}= \\
\vdots \\
\vdots\end{array}$ \\
\hline$\stackrel{\Xi}{\Xi}$ & $\begin{array}{l}= \\
\stackrel{\rho}{q}\end{array}$ & $\begin{array}{l}= \\
\vec{n}\end{array}$ & $\begin{array}{l}= \\
\approx\end{array}$ \\
\hline$\stackrel{x}{\cong}$ & $\begin{array}{l}= \\
\approx\end{array}$ & $=$ & $\begin{array}{l}= \\
5\end{array}$ \\
\hline
\end{tabular}

\begin{tabular}{|c|c|c|}
\hline$\stackrel{4}{2}$ & 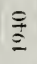 & $\tilde{i}$ \\
\hline$\frac{\hat{3}}{2}$ & $\hat{\Xi}$ & $\approx$ \\
\hline
\end{tabular}

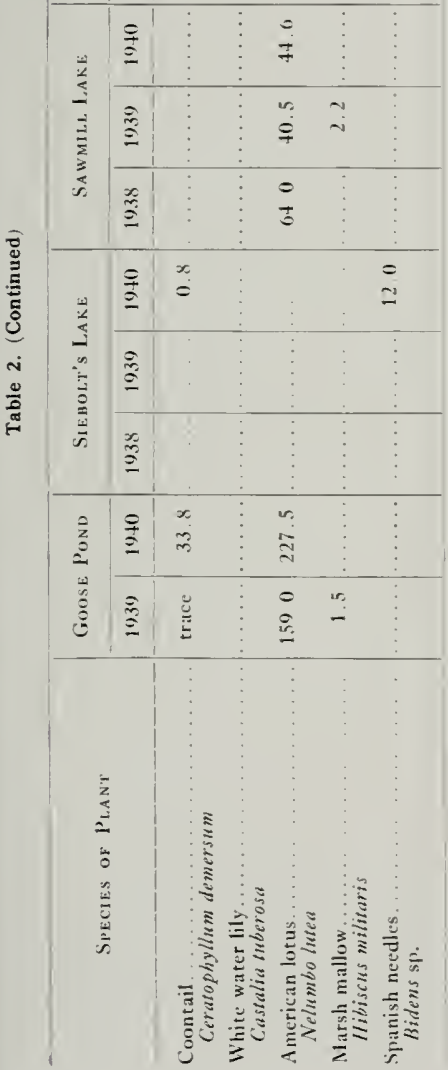

cies. A similar procedure was followed in 1939 and 1940 . The resulting data appear in tables $1-5$.

Base maps for plotting the regetation, water depths and transparency readings were traced from U. S. Engineer, Illinois River valley waterway, maps scaled 1 inch to 1,000 feet. Plant beds were drawn by aspection and rough triangulation, of ten aided by exact outlines of marsh growth on the base map. I have no delusions that this method approaches perfection, but after rechecking certain areas during 1939 and $1940 \mathrm{I}$ feel that a maximum error in data of emergent species is 10 per cent, and in data of submerged and floating aquatic plant beds is 25 per cent. Density of small, scattered patches of aquatic species. such as coontail, sago and longleaf pondweeds.* was determined by measuring the size of patches and estimating the number of patches per unit area.

\section{Effect of Various Water Levels}

Botanically, as well as hydrographically. lakes in the Illinois River valley may be placed in classes based on water levels. As lakes change from one hydrographic class to another, there is a lag of varying lengths in the aquatic regetation change to conform with the altered water levels. Thus, while the water levels of Douglas Lake changed from semistabilized to stabilized conditions in 1939 , the plant communities remained largely typical of a semistabilized area throughout 1940 . On the other hand, aquatic plants of such fluctuating lakes as Siebolt's and Sawmill, and of Goose Pond, approached the characteristic of a semistabilized type in a single vear. The plants of these lakes were classified with vegetation of semistable waters in table 8 .

For convenience, lakes have been classified as follows: Class I. lakes with stable waters; Class II. lakes with semistable waters: and Class III. lakes with fluctuating waters.

Certain plants are more tolerant of environmental conditions than others and may exist under a variety of conditions. Tables 6-8 reveal American lotus, river bulrush, marsh smartweed and duck potato to be among the most tolerant aquatic spe-

\footnotetext{
* Common names of plants are used throughout the text. The equivalent scientific names are included in text. The equivalent scientific
the tables and in the appendix.
} 


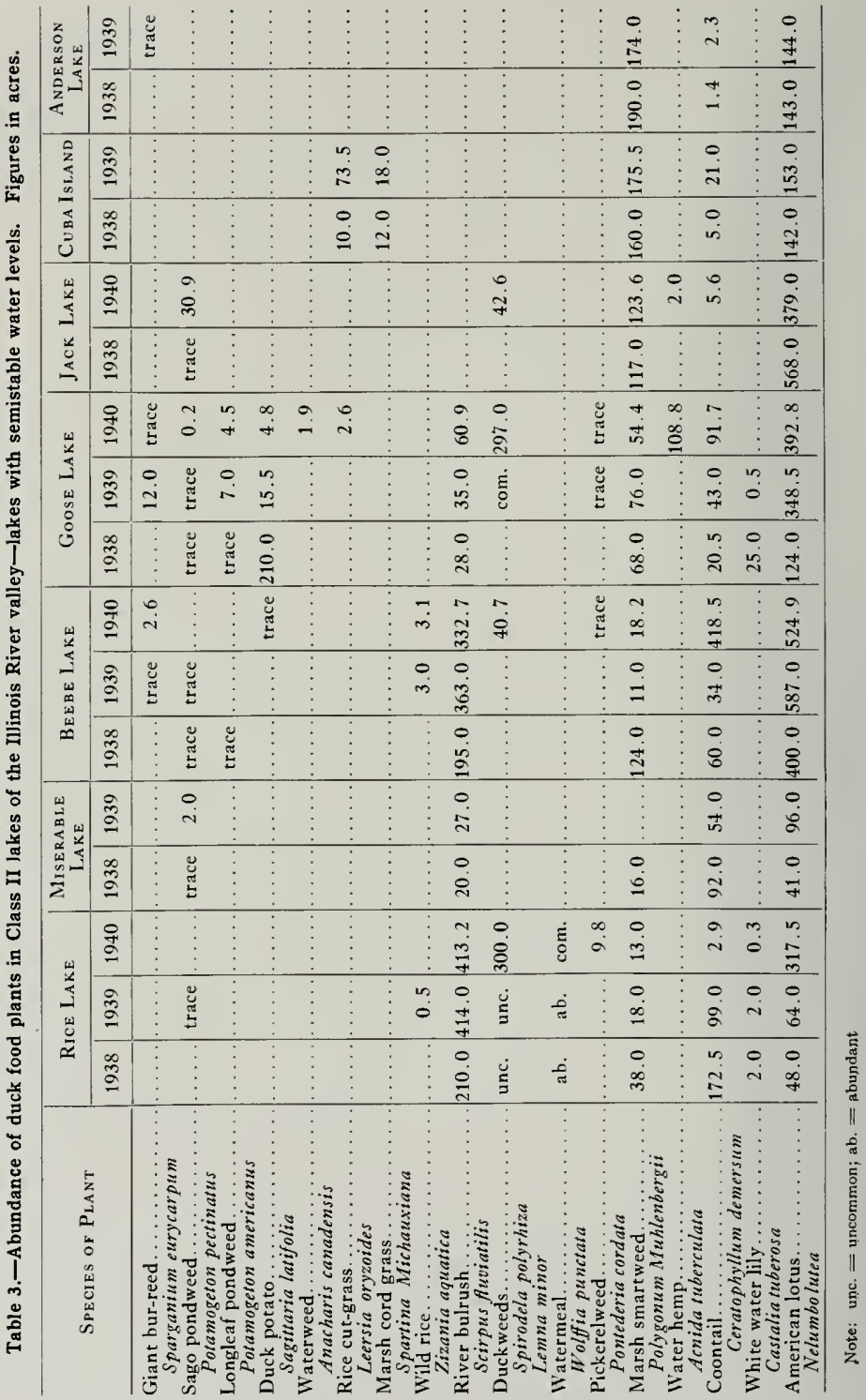




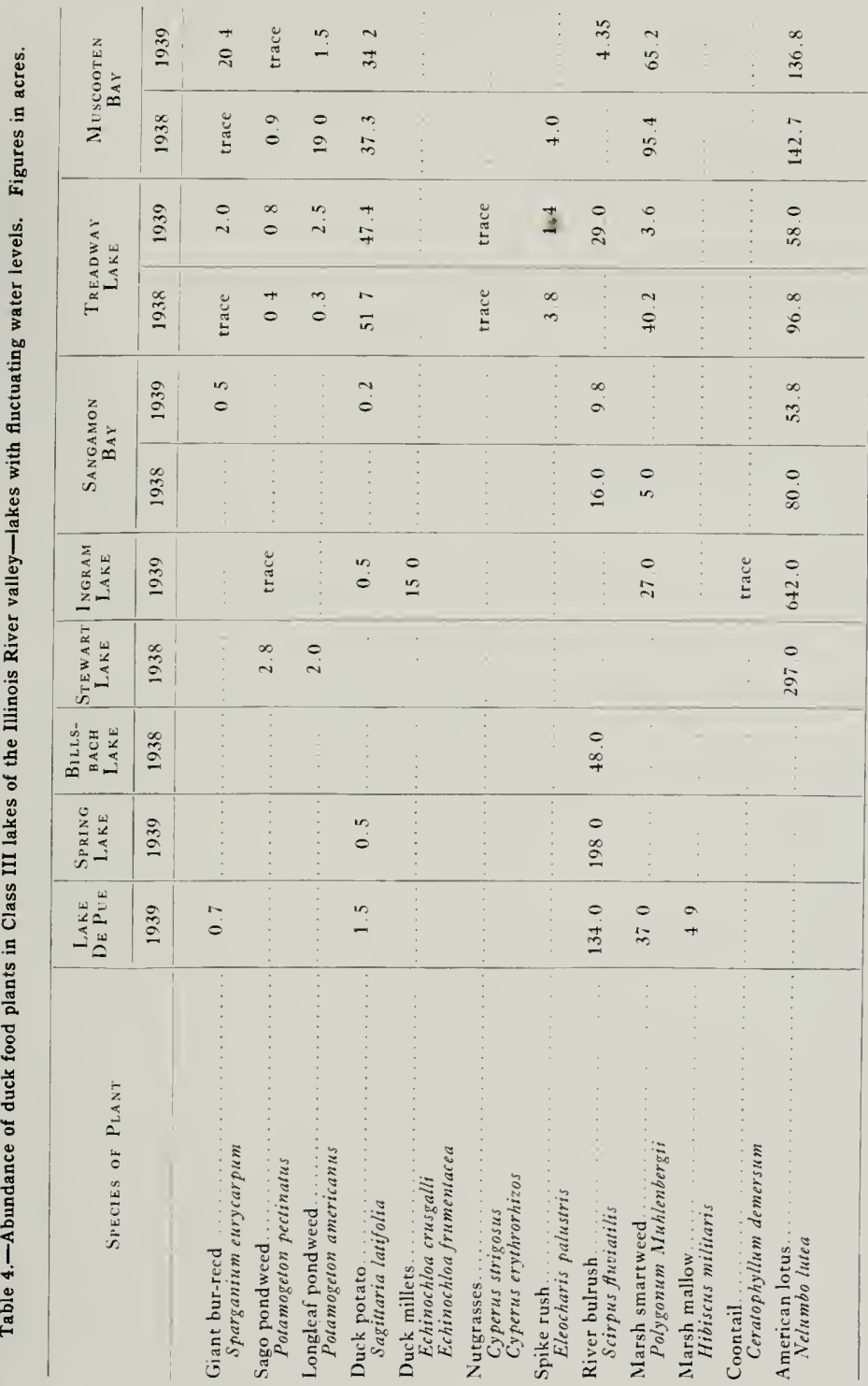




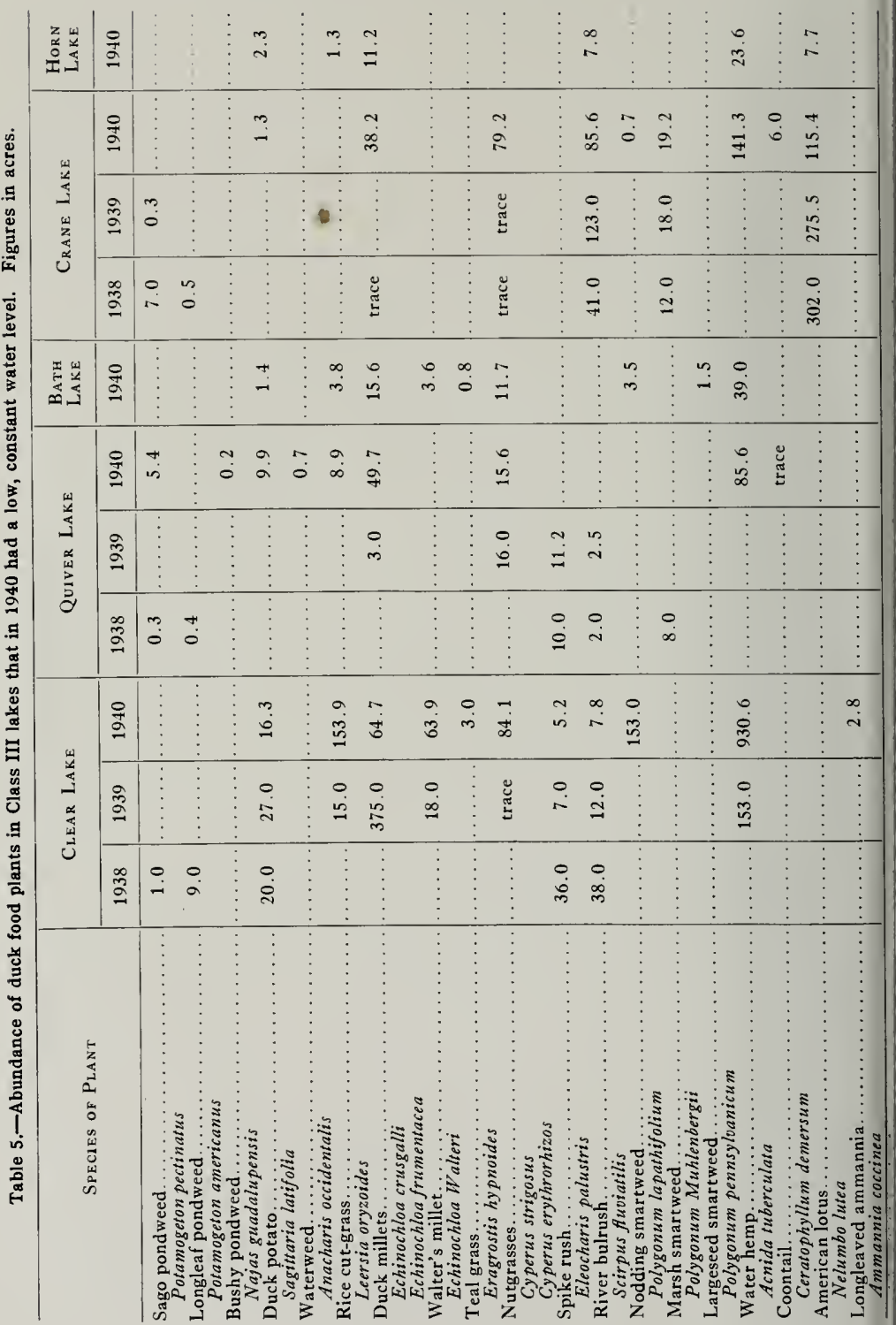


cies. Other plants are unable to live under varying environmental conditions. Bushy pondweed, cattail, teal grass, millet and water hemp, as shown by tables $6-8$, belong to this second type.

Examination of tables 1- 8 discloses that water levels are a major influence on the Illinois River valley waterfowl habitat. Changes in levels have caused the decline or extinction of many areas as duck feeding grounds, and the creation or improvement of others. A few grounds have remained stabilized, but the majority have been subject to yearly, if not seasonal, changes.

Class I Lakes, Stabilized Waters.Tables 1 and 2, as well as 6,7 and 8 , affirm the importance of stabilized water levels to submerged aquatic plants. In lakes with stable waters, the pondweeds. sago, longleaf and bushy, covered a larger percentage of area than any other aquatic plant, according to these last three tables.

Lake Chautauqua. figs. 9 and 10 , is the best example of this class. Levees and control gates aid in maintaining a fairly constant water level, which resulted in the tormation of large beds of pondweeds and coontail in 1938 .

In 1938 and early 1939. Douglas Lake was a semistabilized lake; the other bodies of water represented in table 2 were in the fluctuating class. With a greater stabilization of water levels by the Peoria dam, fig. 5, a decided shift toward submerged aquatic plants was noted in these lakes in 1939 and 1940. Sago pondweed acreage increased from 1 to 13 acres at Goose Pond, from 0 to over 281 acres at Siebolt's Lake and from 0 to 5 to 115 acres at Sawmill Lake. Waterweed increased from a trace to 6.t acres at Douglas Lake. Coontail increased from a trace to 33.8 acres at Goose Pond, from 0 to 0.8 acre at Sie-

Table 6.-Aquatic plants and their relative abundance, expressed in percentage of total acreage of plants in 2 stable, 9 semistable and 8 fluctuating lakes of the Illinois River valley, August, 1938.

\begin{tabular}{|c|c|c|c|c|}
\hline Species of Plant & STABLE & SEMISTABLE & FLECTLATING & TOTAL \\
\hline $\begin{array}{l}\text { American lotus ............... } \\
\text { Velumbo lutea }\end{array}$ & 0.5 & 18.3 & 11.9 & 30.7 \\
\hline $\begin{array}{l}\text { River bulrush . } \\
\text { Scirpus furiailis }\end{array}$ & 0.6 & $20 \div$ & 4.5 & 25.8 \\
\hline $\begin{array}{l}\text { Marsh smartweed } \\
\text { Polygonum . Wuhlenbergii }\end{array}$ & 1.6 & 9.3 & 1.4 & 12.3 \\
\hline $\begin{array}{l}\text { Coontail. ... } \\
\text { Ceratophyllum demersum }\end{array}$ & i. 3 & 46 & & 11.9 \\
\hline $\begin{array}{l}\text { Longleaf pondweed...... } \\
\text { Posamogeion americanus }\end{array}$ & 5.6 & trace & 04 & 6.0 \\
\hline $\begin{array}{l}\text { Duck potato. . . . . . . . . } \\
\text { Sagiltaria latifolia }\end{array}$ & 0.4 & 2.9 & 1.4 & 4.7 \\
\hline $\begin{array}{l}\text { Sago pondweed } \\
\text { Potamogeton pectinatus }\end{array}$ & 3.6 & trace & 0.2 & 3.8 \\
\hline $\begin{array}{l}\text { Smartweeds.............. } \\
\text { Polygonum spp. }\end{array}$ & 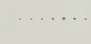 & 1. 6 & . & 1.6 \\
\hline $\begin{array}{l}\text { Bushy pondweed ...... } \\
\text { Najas guadalupensis }\end{array}$ & 10 & & . & 1.0 \\
\hline $\begin{array}{l}\text { Waterweed . . Anacharis canadensis } \\
\text { An }\end{array}$ & 09 & & & 09 \\
\hline $\begin{array}{l}\text { Spike rush ............ } \\
\text { Eleocharis palustris }\end{array}$ & & i & 0.6 & 0.6 \\
\hline 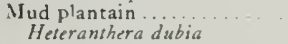 & 0.3 & & & 0.3 \\
\hline $\begin{array}{l}\text { Rice cut-grass } \\
\text { Leersig oryzoides }\end{array}$ & & & & 0.2 \\
\hline $\begin{array}{l}\text { Marsh cord grass... } \\
\text { Sparina . Michauxiana }\end{array}$ & & 0.2 & & 0.2 \\
\hline $\begin{array}{l}\text { Wild rice. ........... } \\
\text { Zizania aquatica } \\
\text { White water lily...... } \\
\text { Castalia tuberosa }\end{array}$ & & $\begin{array}{l}\text { trace } \\
\text { trace }\end{array}$ & & 1 \\
\hline $\begin{array}{l}\text { Giant bur-reed. } \\
\text { Sparganium eurvcarpum }\end{array}$ & & & trace & 1 \\
\hline Total............ . & 21.8 & 57.8 & 20.4 & 1000 \\
\hline
\end{tabular}


bolt's Lake and from 32 to 40 to over 103 acres at Douglas Lake. With the greater stabilization of the water, wild rice occurred in abundance during 1939 and 1940 at Douglas Lake.
Cursory inspection of Peoria Lake in 1938 revealed a few scattered beds of bushy, sago and longleaf pondweeds, and one wild celery bed of approximately 10 acres. The wild celery bed was located

Table 7.-Aquatic plants and their relative abundance, expressed in percentage of total acreage of plants in 3 stable, 7 semistable and 9 fluctuating lakes of the Illinois River valley, August, 1939.

\begin{tabular}{|c|c|c|c|c|}
\hline Species of Plant & StABLE* & SEMISTABLE & Fluctuating & TOTAL \\
\hline $\begin{array}{l}\text { River bulrush. ..................... } \\
\quad \text { Scirpus fluviatilis }\end{array}$ & 0.6 & 21.4 & 14.1 & 36.1 \\
\hline 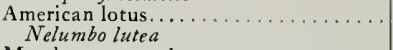 & 0.1 & 16.3 & 12.0 & 28.4 \\
\hline $\begin{array}{l}\text { Marsh smartweed............................. } \\
\text { Polygonum Muklenbergii }\end{array}$ & 1.6 & 4.6 & 1.8 & 8.0 \\
\hline 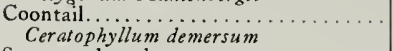 & 4.5 & 3.1 & trace & 7.6 \\
\hline $\begin{array}{l}\text { Sago pondweed..................... } \\
\text { Potamogeton pectinatus }\end{array}$ & 4.2 & trace & 0.2 & 4.4 \\
\hline $\begin{array}{l}\text { Wild millet } \\
\text { Echinochloa crusgalli }\end{array}$ & & $\cdots$ & 3.8 & 3.8 \\
\hline $\begin{array}{l}\text { Duck potato ... } \\
\text { Sagittaria latifolia }\end{array}$ & 0.7 & 0.3 & 1.2 & 2.2 \\
\hline $\begin{array}{l}\text { Longleaf pondweed .................. } \\
\text { Potamogeton americanus }\end{array}$ & 1.5 & trace & trace & 1.5 \\
\hline $\begin{array}{l}\text { Water hemp...................... } \\
\text { Acnida tuberculaia }\end{array}$ & $\ldots$ & $\cdots$ & 1.5 & 1.5 \\
\hline $\begin{array}{l}\text { Rice cut-grass....................... } \\
\text { Leersia oryzoides }\end{array}$ & $\cdots$ & 0.8 & 0.2 & 1.0 \\
\hline $\begin{array}{l}\text { White water lily..................... } \\
\text { Castalia tuberosa }\end{array}$ & & 0.9 & . & 0.9 \\
\hline 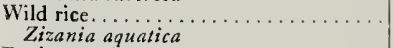 & & 0.8 & & 0.8 \\
\hline $\begin{array}{l}\text { Bushy pondweed .......................... } \\
\text { Najas guadalupensis }\end{array}$ & 0.8 & trace & & 0.8 \\
\hline 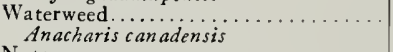 & 0.7 & & & 0.7 \\
\hline $\begin{array}{l}\text { Nutgrasses............................... } \\
\text { Cyperus strigosus } \\
\text { Cyperus erythrorhizos }\end{array}$ & . & $\cdots$ & 0.5 & 0.5 \\
\hline $\begin{array}{l}\text { Giant bur-reed............................ } \\
\text { Sparganium eurycarpum }\end{array}$ & & 0.1 & 0.3 & 0.4 \\
\hline $\begin{array}{l}\text { Walter's millet. } \\
\text { Echinochloa } V_{\text {alieri }}\end{array}$ & & . & 0.3 & 0.3 \\
\hline $\begin{array}{l}\text { Mud plantain. .. } \\
\text { Heteranthera dubia }\end{array}$ & 0.3 & & & 0.3 \\
\hline Spike rush............................. & & & 0.2 & 0.2 \\
\hline $\begin{array}{l}\text { Marsh cord grass.................... } \\
\text { Spartina Michauxiana }\end{array}$ & & 0.2 & . & 0.2 \\
\hline Cattail................................ & 0.2 & 0 & . & 0.2 \\
\hline $\begin{array}{l}\text { Pickerelweed, .................... } \\
\text { Pontederia cordata }\end{array}$ & & 0.1 & & 0.1 \\
\hline $\begin{array}{l}\text { Marsh mallow............................... } \\
\text { Hibiscus militaris }\end{array}$ & & & 0.1 & 0.1 \\
\hline $\begin{array}{l}\text { Reed cane................................... } \\
\quad \text { Phragmites communis }\end{array}$ & & trace & & \\
\hline $\begin{array}{l}\text { Nodding smartweed........... } \\
\text { Polygonum la pathifolium }\end{array}$ & & trace & trace & \\
\hline $\begin{array}{l}\text { Cocklebur................ } \\
\text { Xanthium sp. }\end{array}$ & & & trace & \\
\hline Total. . & 15.2 & 48.6 & 36.2 & 100.0 \\
\hline
\end{tabular}

*Cursory inspection showed vegetation in Spring Lake in 1939 similar to that in 1938; so its 1938 figures were added to this table. 
Table 8.-Aquatic plants and their relative abundance, expressed in percentage of total acreage of plants in 2 stable, 9 semistable and 5 fluctuating lakes of the Illinois River valley, August, 1940.

River bulrush Scirpus fuciatilis

American lotus... Nelumbolutea

IV a ter hemp... tcnida tuberculara

Coontail... Ceratophyllum demersum

Duckweeds............ Spirodela polyrhiza Lemna minor

Sago pondweed Potamogeron pectinatus

Marsh smartweed Polygonum . Muhlenbergit

Longleaf pondweed

Polamogeton americanus

Nutgrasses.

Cyperus strigosus

Cyperus eryihrorhizos

Duck millets........... Echinochloa crusgalli Echinochloa frumentacea

Rice cut-grass.

Leersia oryzoides

Nodding smartweed Polygonum lapathifolium

Duck potato.

Sagittaria latifolio

Walter's millet. Echinochloa II alteri

Cattail...... Typha angustifolia

Wild rice. . . . . . . . Zizania aquatica

Pickerelweed.... Pontederia cordata

White water lily.... Castalia tuberose

Wild celery. Vallisneria spiralis

Spanish needles... Bidens sp.

Bushy pondweed Vajas guadalupensis

Small pondweed Potamogeton pusillus

Waterweeds Anacharis canadensis Anacharis occidentalis

Dotted smartweed . . Polygonum punctata

Spike rush. Eleocharis sp.

Teal grass. . Eragrostis hypnoides

Giant bur-reed.

Sparganium eurycarpum

Longleaved ammania..... Ammannia coccinea

\begin{tabular}{|c|c|c|c|}
\hline STABLE & Semistable & Flectuatisg & Totat. \\
\hline 0.14 & 28.62 & 0.97 & 29.73 \\
\hline \multirow[t]{2}{*}{1.92} & 20.40 & $1.3 t$ & 23.66 \\
\hline & 1.16 & 1152 & 12.68 \\
\hline \multirow[t]{2}{*}{1.63} & 6.10 & 0.05 & 7.78 \\
\hline & 5.04 & . & 5.04 \\
\hline 0.65 & 3.92 & 005 & 4.62 \\
\hline 1.30 & 245 & 0.18 & 393 \\
\hline \multirow[t]{4}{*}{2.04} & 0.05 & $\ldots$ & 2.09 \\
\hline & $0.0^{\circ}$ & 1.83 & 1.92 \\
\hline & & 1.60 & 166 \\
\hline & 0.09 & 1.56 & 165 \\
\hline . & 0.07 & 1.48 & 155 \\
\hline \multirow[t]{2}{*}{0.78} & 0.21 & 0.29 & 1.28 \\
\hline & 0.03 & 0.63 & 0.66 \\
\hline \multirow[t]{4}{*}{0.39} & & & 0.39 \\
\hline & 0.29 & . & 0.29 \\
\hline & 0.26 & & 0.26 \\
\hline & 0.23 & & 0.23 \\
\hline \multirow[t]{2}{*}{0.12} & & & 0.12 \\
\hline & 0.11 & 11 & 0.11 \\
\hline 0.08 & . & & $00 s$ \\
\hline \multirow[t]{7}{*}{$0.0 i$} & & & 0.07 \\
\hline & 005 & trace & 0.05 \\
\hline & 0.04 & . & 0.04 \\
\hline & & $\begin{array}{lll}0 & 04\end{array}$ & 0.04 \\
\hline & $\cdots$ & 0.03 & 0.03 \\
\hline & 0.02 & & 0.02 \\
\hline & 0.02 & & 0.02 \\
\hline 912 & 69.25 & 21.63 & 100.00 \\
\hline
\end{tabular}


between Upper and Lower Peoria lakes. Increased stabilization of water in 1939 resulted in bushy, sago and longleaf pondweed and coontail beds much greater in extent. With continued regular water levels in 19+0, wild celery, sago and bushy pondweeds and coontail appeared throughout Upper Peoria Lake. Also a smattering of waterweed was found in 1940.

Class II Lakes, Semistabilized Waters. -According to tables 6,7 and 8 , river weed covered no more than 3 acres, longleaf pondweed no more than 19 acres and coontail no more than a trace in any lake of this class. American lotus was about as abundant in lakes of this class as in lakes of Class II.

Among the emergent species, duck po-

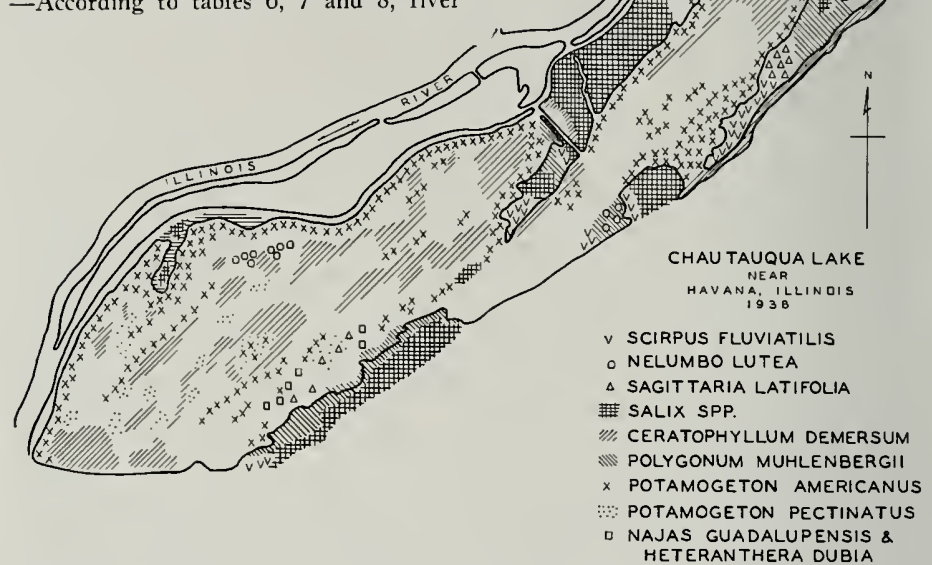

Fig. 9.- Vegetation map of Lake Chautauqua, showing location of principal duck food beds, 1938. Because of the great reduction necessary, the outlines in this and other similar maps have been simplified. Note extensive beds of longleaf pondweed (Potamogeton americanus) and coontail (Ceratophyllum demersum) through much of the lake; also extensive marsh smartweed beds (Polygonum Muhlenbergii) in and among tracts of willow (Salix spp.).

bulrush, American lotus, marsh smartweed and coontail were the predominant species in lakes with semistable water levels. Table 3 indicates that coontail in Class II lakes covered large areas that compared favorably in size with the areas of this plant found in Class I lakes. Sago and longleaf pondweeds occurred in only small quantities in Class II lakes. Other significant facts to be noted in table 3 are the presence of rice cut-grass and wild rice, the absence of wild celery and the scarcity of waterweed. Goose Lake, fig. 11, is typical of this class except that it contains an unusually large bed of duck potato.

Class III Lakes, Fluctuating Waters.As shown in tables 4, 6 and 7, lakes with fluctuating water levels may be almost devoid of submerged and floating aquatic plants. Table 4 discloses that sago pond- tato covered as much as 51 acres, giant burreed as much as 20 acres and marsh smartweed as much as 95 acres in a single lake of Class III. River bulrush covered 198 acres in one lake of this class. This was considerably less than the 414 acres found in a comparable Class II lake. Muscooten Bay, fig. 8, was in 1938 a typical Class III lake.

Lakes of Class III occasionally undergo an early summer metamorphosis, during which the water recedes to expose broad, extensive mud flats. In the summer of 1936 , and to a lesser extent in 1937, many moist-soil plants of value as duck foods grew on these mud flats. Such plants as nutgrasses, wild millet, teal grass, nodding and largeseed smartweeds and water hemp or pigweed made up the bulk of this vegetation. Data in table 6, however, show 
that during 1938 there was little development of such plants in the lllinois River valley. A glance at fig. 6 helps to explain this situation. The water remained high in lakes of this type throughout July. Shortly after the water level dropped in August, exposing mud flats, a subsequent rise drowned the immature moist-soil plants commencing to appear.

In 1938, Clear Lake had a dearth of moist-soil plants. In 1939 , it had an occurred in the Havana region in the latter part of June and throughout July, $19+0$, than in the equivalent 1939 period. Consequently, an unusual development of wild and Japanese millets, nutgrasses, smartweeds and water hemp occurred in $19+0$, table 5, on the mud flats of Quiver,

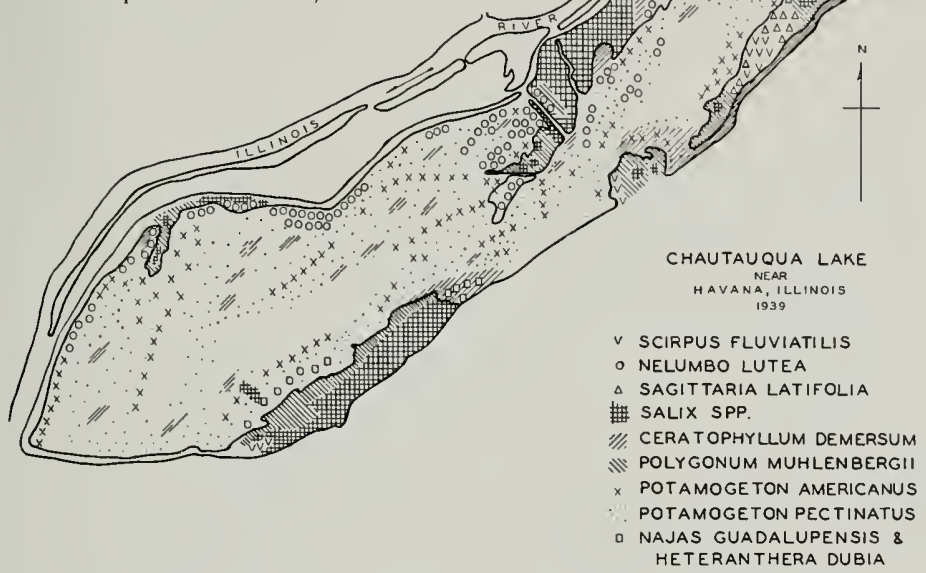

Fig. 10. - Vegetation map of Lake Chautauqua showing location of principal duck food heds, 1939. Compare this map with that for 1938. Note the increase in American lotus (Velumbo lutea). Note also the decrease in coontail (Ceratophyllum demersum) and longleaf pondweed (Potamogeton americanus). Sago pondweed (Potamogeton pectinatus) showed an increase in 1939 but has since suffered a marked decline. The decrease in these three species started after 1937, when the levees were repaired, and has continued because the water depth has been held too high for sufficient light intensity to reach those plants that were established when the lake was shallower. A stabilized water level of increased depth has resulted in an encroachment of duck potato (Sagittaria latifolia) on river bulrush (Sfirpus fuviatilis).

abundance of such plants, table 5. This change represents a typical metamorphosis of Class III lakes. As indicated by fig. 6, the water level of the Illinois River at Havana, a few miles below Clear Lake, averaged about 2 feet lower during July, 1939, than during July, 1938, and lower still during August and September, 1939. The low water caused much of the shallow, flat Clear Lake basin to be exposed as mud flats, on which moist-soil plants rapidly grew as the water receded. The water was too high at other bodies of water to expose mud flats of appreciable size.

As shown in fig. 6 , a lower water stage
Bath, Clear, Crane, Horn and other lakes. At Clear Lake, fig. 12, water hemp covered over 930 acres, nodding smartweed 153 acres, nutgrasses over $8+$ acres and millets over 128 acres. Horn Lake, completely covered by American lotus in 1939 , had 11.2 acres of Japanese millet and over 23 acres of water hemp in 1940.

\section{Effect of Floods}

Severe floods have at various times in the past poured through the Illinois valley. Exceptionally high water prevailed in most of the summer of 1927. This, it is reported, wiped out almost all the Ameri- 
can lotus beds in the region and drowned innumerable pecan trees in the bottoms above Beardstown.

In 1938 the water level, after dropping in mid May, rose 2 to 3 feet in June and July, figs. +6 . Such a small rise had no effect on the American lotus, fig. 13, the leaves of which rose with the water, but it left its mark on several other species. by 2 feet of water. TVhen mapping was done in August, there was scarcely a leaf left on the plants, which were covered with sediment. They failed to flower. Thus it

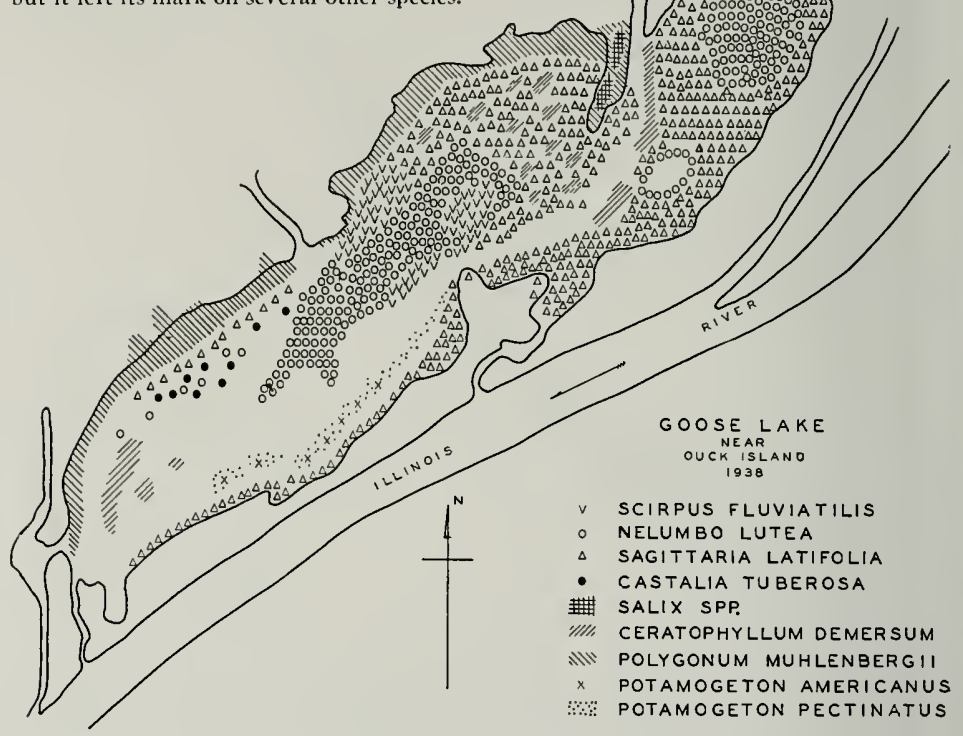

Fig. 11. - Vegetation map of Goose Lake, showing location of principal duck food beds, 1938. This lake is near Duck Island, a few miles south of Banner. Here semistable water levels resulted in large beds of duck potato (Sagittaria latifolia), marsh smartweed (Polygonum Muhlenbergii) and American lotus (Nelumbolutea). High water in the spring of 1938 resulted in the disappearance the following year of much of the duck potato bed, the areas being taken over by river bulrush (Scirpus fiuviatilis), American lotus (Nelumbo lutea) and coontail (Ceratophyllum demersum). Note the scarcity of longleaf and sago pondweeds (Potamogeton americanus and $P$. pectinatus).

For instance, only a trace of sago pondweed remained in Jack Lake in August, 1938, table 3, although in late May the lake had innumerable patches scattered over the area of several hundred acres. From the August appearance and association of the remaining patches, it was obvious that the greater part of the sago pondweed had been killed by the high water of June and July.

Table 3 shows 210 acres of duck potato at Goose Lake in 1938, fig. 11. A survey in June revealed these plants to be covered is no wonder that only 15.5 acres of duck potato remained in 1939, and only 4.8 acres in 1940. River bulrush and American lotus occupied the vacated areas.

River bulrush, figs. 14,15 and 16 , began to send up shoots from its large tubers in mid May, 1938. With the high water in June and July of that year, fig. 6, many beds of river bulrush were inundated and the plants killed. Marsh smartweed stems and foliage, which rose with the water, were not inundated, and this smartweed began to spread over areas formerly 
occupied by the river bulsush. Later, with the return of low water in August, a second growth of bulrush stems appeared from the resistant tubers. In 1939, with low water in June and July, river bulrush regained areas it had lost to marsh smartweed. With low water in $19+0$, river bulrush invaded marsh smartweed beds in several places.

Table 3 indicates the shift in abundance of these species at Rice, Miserable, Beebe and Goose lakes over a 3-year period. At herhaceous plants to develop; it is also conducive to growth of willows, cottonwoods and buttonbush, plants of little value as sources of waterfowl food. In 1940 , several areas of the exposed basins of Crane and Horn lakes were covered with seedling willows and cottonwoods. There is evidence that in other lakes willows and buttonbush, figs. 17 and 18 , have in the past invaded exposed areas in periods of low water and maintained their position with the return of higher water. Thus,

$$
\begin{gathered}
\text { CLEAR LAKE } \\
\text { LIVERPOOLEAR ILLINOIS } \\
\text { I } 940
\end{gathered}
$$

WhM ECHINOCHLOA FRUMANTACEA

WHIII POLYGONUM LAPATHIFOLIUM

ECHINOCHLOA WALTERI

- eleOCHARIS palustris

r LEERSIA ORYZOIDES

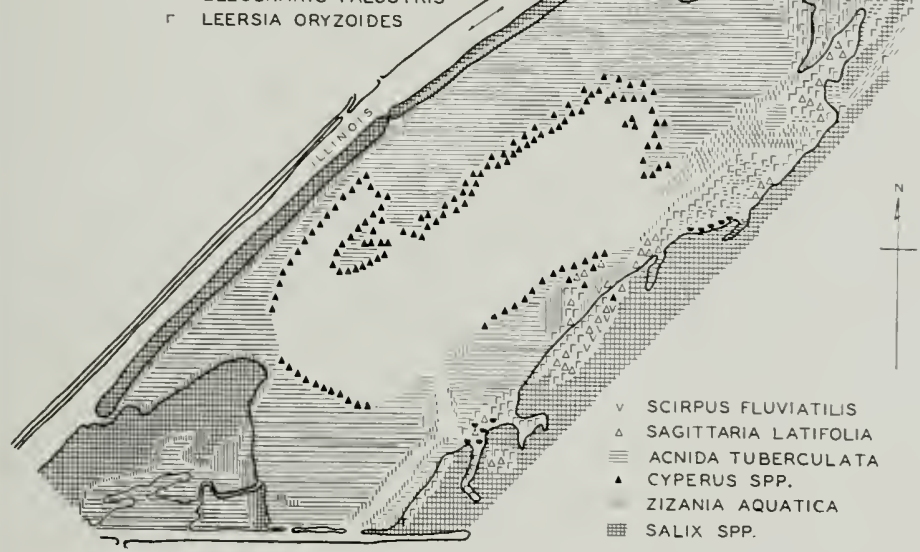

Fig. 12.-Vegetation map of Clear Lake, showing location of principal duck food beds, 1940. Clear Lake in 1940 was an excellent mallard and pintail feeding ground because of the extensive beds of moist-soil plants. Japanese and Walter's millets (Echinochloa frumanfacea and E. II'alteri), nutgrasses (Cyperus strigosus and $C$. ervthrorhizos), water hemp or pigweed (.tcnida tuberculata) and nodding smartweed (Polygonum lapalhifolium) appeared on the exposed mud flats shortly. after recession of the water in early summer. A small levee was constructed to enable springs and rains to flood these beds during the hunting season.

Beebe Lake, for example, marsh smartweed shifted from 124 acres to 11 acres to 18.2 acres; river bulrush, from 195 acres to 363 acres to 332.7 acres.

\section{Effect of Drought}

Drought not only lowers water levels sufficiently to allow desirable moist-soil they often become a pest by encroaching upon waterfowl feeding grounds during drought periods.

While various factors not understood at the present time may be partly responsible, 1 believe that the low water in Rice Lake in 1940 , resulting from drought, was the principal cause of an increase in American lotus from of to over 317 acres, 


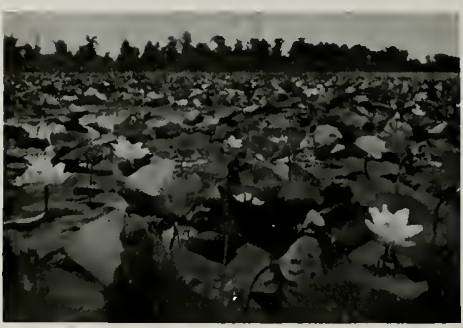

Fig. 13.-American lotus (Nelumbo lutea), also known as yorkey nut. Able to withstand fuctuating water levels, it is very abundant, but unfortunately is a poor duck food. Seldom do ducks consume the hard, nutlike seeds of this plant.

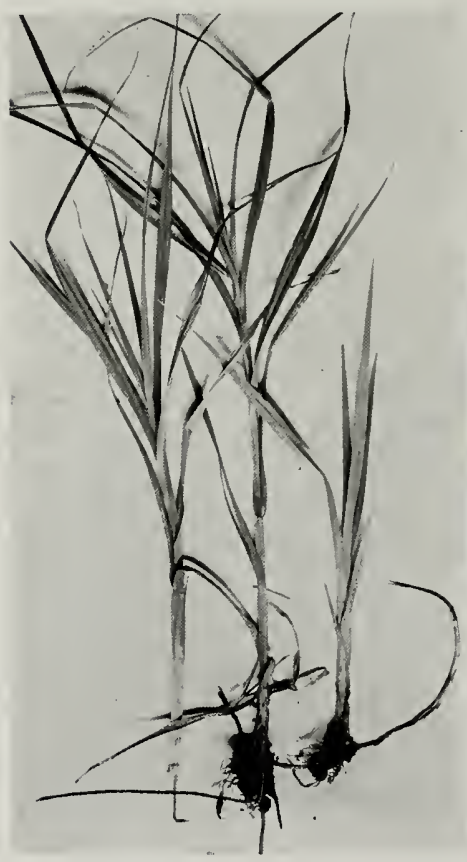

Fig. 14.-River bulrush (Scirpus fuviatilis). This is often called flag in the Illinois River valley, where it covers thousands of acres. It is of little value as a waterfowl food plant, since it rarely produces seed. It reproduces by means of woody tubers and rootstocks. table 3 , with a corresponding decrease in coontail, a more valuable duck food plant, from 99 to 2.9 acres. Adjoining Beebe Lake, although lowered by the drought, averaged 8 inches deeper than Rice Lake. In Beebe Lake, coontail increased from $3+$ to over +18 acres, although American lotus was present in much of the same area. This increase in coontail was undoubtedly the result of shallower water, which was still not too shallow and which allowed greater bottom light intensity.

\section{Effect of Water Fluctuation}

The importance of fluctuating water levels as a factor affecting aquatic plants has been discussed, but the manner in which these levels directly influence various plants needs explanation.

Fluctuating water levels affect aquatic plants in several ways. During flood times in spring and early summer, adequate sunlight does not penetrate sufficiently deep to enable aquatic plants to make normal growth, as in their customary depths of water. If aquatic plant beds become established in the shallows during periods

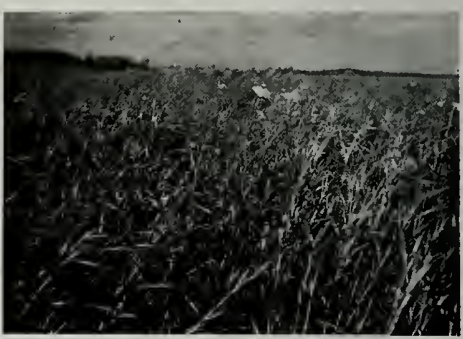

Fig. 15.-An extensive bulrush bed at Rice Lake; a few fruiting heads of American lotus are visible.

of high water, these same beds are exposed with the return of normal or lower levels to drying and to fermentation of the vegetative parts. This exposure not only prevents waterfowl from utilizing the plants as food, but it also usually results in failure of the plants to reproduce. As pointed out elsewhere, American lotus and river bulrush, among the less valuable waterfowl food sources, are two of the few plants tolerant of such severe physical conditions. 
Fluctuating water levels affect such marsh and moist-soil plants as wild and Walter's millets, figs. 19-20, chufa, rice cut-grass, certain smartweeds and pigweed, as well as aquatic plants. When these plants are inundated in their immature more turbid the waters, the shallower becomes the maximum depth at which various species of aquatic plants are able to live.

During the summer of 1939 and 1940 , the transparency of many lakes along the

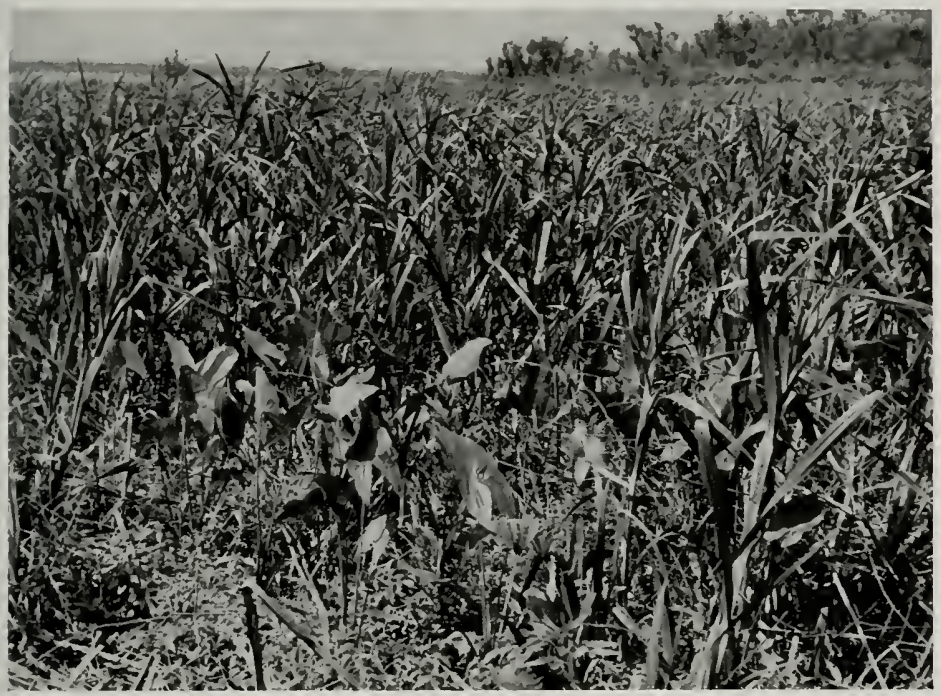

Fig. 16. - Remnant of a hed of duck potato (Sagitharia latifolia) being encroached upon by river bulrush (Scirpus fuviatilis) in an area from which water has receded.

stages, as they frequently are during the summer, they drown through lack of sufficient carbon dioxide and oxygen. The more mature these plants become, the longer they are able to tolerate flooding. In 1938 and 1939, many seedling Japanese millet patches planted by duck clubs failed to develop because of inundation in July or August.

\section{Factors Influencing Turbidity}

With the exception of fluctuating water levels, turbidity is apparently the most potent factor affecting aquatic plant beds in the Illinois River region. Turbidity inhibits light penetration. The depth to which submerged and floating aquatic plants grow is dependent largely upon the amount of sunlight they obtain. Thus, the
Illinois River was measured by means of a Secchi disc. This disc is 10 centimeters (t inches) in diameter and white in color. The maximum distance below the water surface that the outline of the disc is visible in the shade is used as a measure of the degree of transparency.

Fluctuating Water Levels. - Physical factors may change the transparency of part of a lake or an entire lake within a few hours. In order to compare transparencies as affected by water levels, it was necessary to consider only those readings not influenced by other factors. The transparency readings at Lake Chautauqua, a lake with stable waters, varied from 8 to 60 inches, with an average of 10 inches. The exceedingly clear water of this lake occurred in a narrow, spring-fed arm that is protected from wind. In lakes 


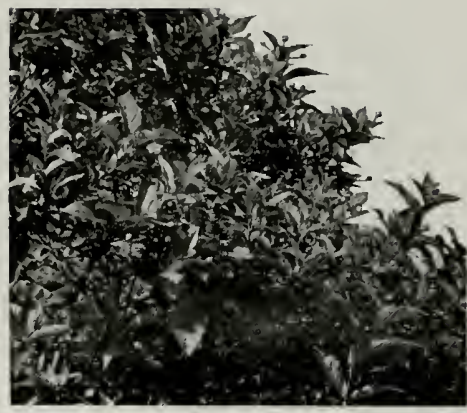

Fig. 17.-Buttonbush (Cephalanthus accidentalis), also called buckbrush. It is a mediocre source of duck food.

with semistable water levels, Secchi readings ranged from 7 to over 32 inches, with an average of 10 inches. At Rice Lake, the d.sc was visible on the bottom at all depths, the greatest depth being 32 inches. Secchi disc readings for lakes with fluctuating water levels varied from 5 to 17 inches, with an average of 8 inches.

Thus, it is apparent that even lakes with stable and semistable water levels in the Illinois River valley have medium to high turbidity. Lakes with fluctuating waters have a greater turbidity, even at times other than flood periods, probably largely because of the paucity of vegeta- tion. In times of high water, Class III lakes become very roily, transparencies being reduced to $t$ inches and less.

Waves.-Waves are frequently as important as floods in causing lake waters to assume a roily condition. Observations made on Lake Chautauqua during the summer of $19+0$ yielded information of importance on this subject. Table 9 reveals that even moderate winds may result in a reduction of the transparency of water from 11 to 6 inches. Waves may stir the bottom soil and produce a high degree of turbidity within an hour or two. Once there is a heavy suspension of soil particles in the water, 1 to 3 days are required before these particles commence to settle noticeably (June 29-July 2, table 9).

Plants may be influential in curtailing turbidity caused by wave action and by fish. In the open water of Goose Pond a strong wind reduced the transparency from 11 to 3 inches in a few hours. In nearby American lotus beds, which contained coontail, the transparency readings ranged between 12 and 20 inches and were the same for identical positions before and after the wind.

At Siebolt's Lake in 1939, Secchi discs disappeared from sight at depths of 6 to 8 inches. No submerged or floating aquatic vegetation was noted in this lake that year, table 2. Following stabilization of water levels, the lake was almost covered by sago pondweed in $19+0$, and the Secchi

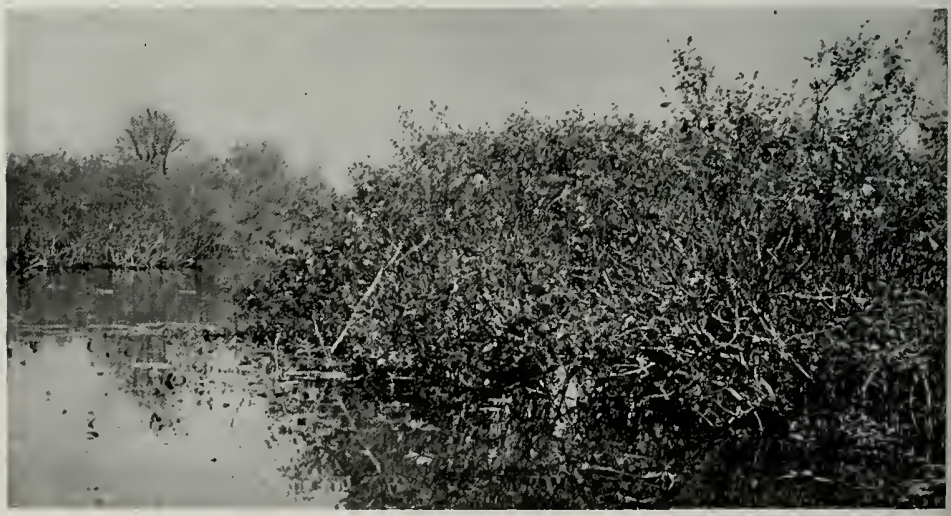

Fig. 18. - Buttonbush often occupies ground that could be utilized by better duck food plants. 
disc was visible 16 inches below the surface. Similar instances in which aquatic plants increased the transparency of the water, through inhibiting wave action, were noted at Sawmill Lake and other places.

Fish.-Rough fish-carp, buffalo, bullheads, catfish, sheepshead and dogfish -

Table 9.-Effect of waves on transparency of Lake Chautauqua, 1940.

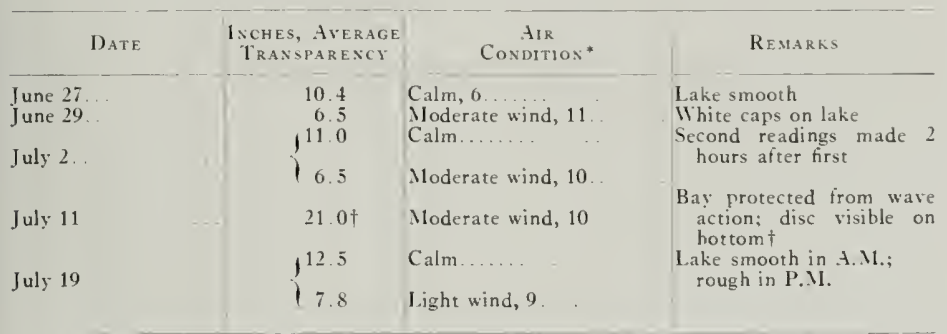

* Maximum miles per hour wind velocity expressed in figures.

tGreatest depth of water at which reading was taken, 21 inches.

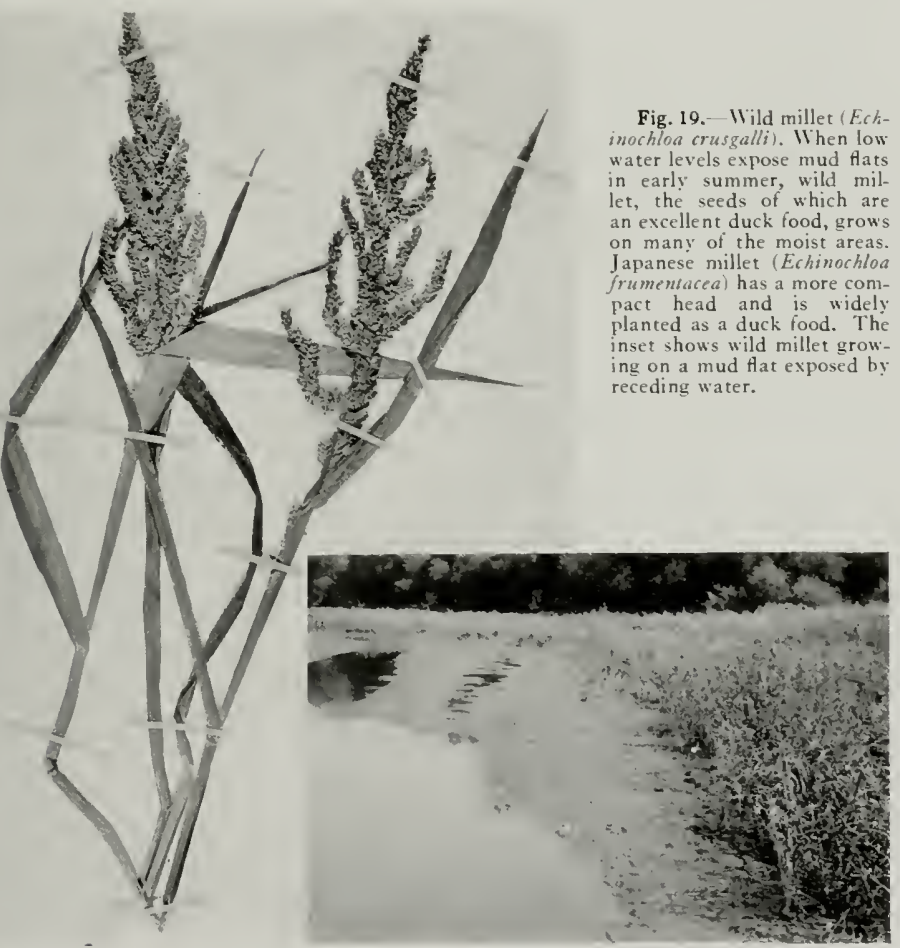


are at times important causes of turbidity in shallow lakes. They evidently create greater turbidity than fine fish because of their bottom-feeding habit. Their influence is more pronounced in shallow than in deep water.

In August, 1938, several turbid areas were noticed in the otherwise fairly clear water of Muscooten Bay. Investigations showed that rough fish were making the waters roily. Since then a like condition has been observed at several other lakes.

At Crystal Lake, in the bottomlands of the Mississippi River, opposite Burlington, Iowa, seining operations disclosed rough fish to be very abundant in 1939. Secchi

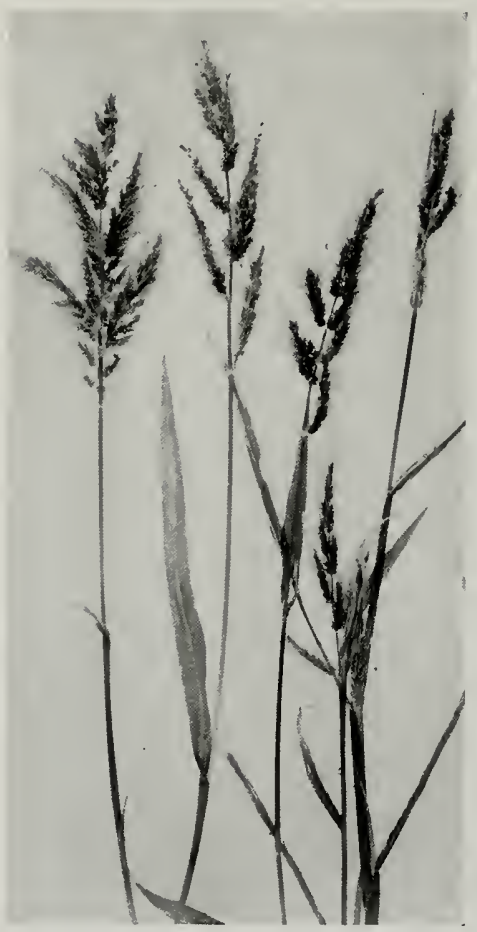

Fig. 20.-Walter's millet (Echinochloa $\mathrm{Wal}$ teri). It has longer awns, smaller seeds and grows in wetter situations than wild millet (Echinochloa crusgalli). Both species are colloquially called corn grass. disc readings taken weekly from May to October of that year showed an average transparency of 15 inches. During the winter of 1939-40, the lake was frozen to such an extent that the rough fish population was greatly reduced. Secchi disc readings made during March and April, 1940 , revealed a transparency of 34 inches. It is believed that rough fish reduced the transparency of these waters by nearly 2 feet.

Lynn Hutchens of the Cook County Forest Preserve District reports in a letter dated Jan. 8, 1941, the effect of fish on the transparency of McGinnis Slough in Cook County. Secchi disc readings in 1939 ran from 6 to 10 inches, with an average of 8 inches. During the winter of 1939-40, 18 inches of ice combined with snow to seal the slough from aeration and to cause the destruction of an estimated 95 per cent of the fish population. Sample counts in April disclosed approximately 50,000 black bullheads and 200,000 golden shiners dead on the shore of the slough. An immediate improvement in the transparency was noted, with Secchi readings averaging 40 inches during the summer of 1940. Fish undoubtedly caused a loss in transparency of at least 30 inches in McGinnis Slough.

Soils. - The composition of soil (i.e., size and binding characteristics of soil particles) influences aquatic plants in Illinois River habitats much more than does fertility of the soil. Waves, currents and fish create greater turbidity where soil particles are fine and loose than where they are coarse or compact.

At Jack Lake, with readings taken in areas of similar depths, transparencies exceeded 20 inches in an area with a hard bottom, while, short distances away, over a soft bottom, transparencies averaged only 7 inches. The transparency of a shallow, silt-bottomed pond near Crane Lake averaged 3 inches. A section of Sawmill Lake having a very soft silt bottom gave a transparency reading of 4 inches; other areas with firmer bottoms gave readings of 19 inches.

Pollution.-In the Illinois River navigation pools above Utica, pollution seems to be an important factor in increasing turbidity. While transparencies in the lower pool (Starved Rock) vary from 13 to 36 inches, transparencies 50 miles up- 
stream (Dresden lsland) vary from 5 to I0 inches. Since each pool acts as a settling basin, the lower one would seem to contain fewer suspended pollution particles. The effect of pollution on aquatic plants is probably largely that of diminishing the amount of sunlight penetrating the water, rather than that of restricting plant growth through lack of dissolved oxygen.

\section{Turbidity and Plant Abundance}

Evidence at hand indicates that an average transparency of less than 9 inches through the growing season almost precludes development of submerged and floating aquatic plants, despite the fact that other conditions may be favorable.

At Crystal Lake, across the Mississippi River from Burlington, Iowa, not a trace of pondweeds or coontail was found in 1939; a transparency of 15 inches was recorded as approximately average at the time. In 1940, with transparency increased to $3 t$ inches, small heds of sago pondweed appeared. A nearby pond, very turbid, contained no plants in 1939. In early 1940 the water cleared sufficiently to make visible a Secchi disc on the bottom at 30 inches. By June the pond contained a mass of muskgrass and leafy pondweed (Potamogeton foliosus).

Hutchens found only a few emergent plants and no submerged or Hoating aquatic plants in McGinnis Slough, Cook County, in 1939, when the water averaged 8 inches in transparencr. He reports that, with the transparency increased to 40 inches in 1940, approximately 28 acres of giant bur-reed appeared. Submerged aquatic regetation developed in the open waters of the lake. One dense bed of muskgrass, coontail and leafy pondweed covered about +4 acres, a bed of muskgrass and coontail covered approximately 98 acres, coontail and leafy pondweed grew on 2.8 acres, and muskgrass and coontail occurred in sparse growth over the rest of the lake. Since other environmental conditions were about the same in both years, it seems obvious that the increase in transparency was responsible for the appearance of aquatic plants in 1940 . A transparency varying between 6 and 10 inches seems to have precluded the growth of aquatic plants at McGinnis Slough in 1939.

\section{Water Depth and Plant Abundance}

The water level of Lake Chautauqua was practically the same from June 1 to Sept. 1 in 1939 and $19+0$, fig. 7 . Although there is only one gauge reading for 1938 . it is known that the water level was about 8 inches higher during the corresponding period in that year. However, the total abundance of coontail, fig. 21, and pondweeds, figs. 22,23 and $2 t$, has steadily decreased, table 1 . These species aggregated about $1, I+9$ acres in 1938.859 acres in 1939 and +41 acres in 1940. It was believed at one time that wind action, combined with water depth, caused the decrease through diminishing transparencr: A check of wind velocity records at Peoria, a short distance away, revealed that the number of dars with a wind velocity of at least 9 miles per hour (for June, July and August) was 52 in 1938, +7 in 1939 and +1 in $19+0$. The total movement of wind for those months was $11,68+$ miles in $1938,10,053$ miles in 1939 and 10.535 miles in 1940. Wind action showed no appreciable increase in the years pondweeds and coontail were decreasing from 1,149 acres to ++1 acres.

The water in Lake Chautauqua was shallower before its levee was repaired in 1938 than after. Perhaps the shallow water prior to 1938 favored establishment of certain aquatic plant beds, while the higher water maintained since then has been too deep to favor germination and propagation of pondweeds and coontail.

In areas of Lake Chautauqua where the Secchi disc normally becomes invisible at 11 inches, scattered patches of coontail grow in water up to $5+$ inches deep. Where the Secchi readings are 60 inches, coontail forms a dense mat 5 to 6 feet deep.

Bushy pondweed evidently requires high transparency. At Lake Chautauqua it grows only where the bottom can be seen, and then only in areas protected from waves creating roily waters. Probably because the water in those areas has become shallower each rear, the bushy pondweed has increased from a trace to 7.3 to 8.6 acres, table 1. At Spring Lake, near Banner, the exceedingly clear water is undoubtedly the reason for abundance ( 78 acres) of this pondweed there.

In Lake Chautauqua areas where the transparency is normally 10 inches, sago 


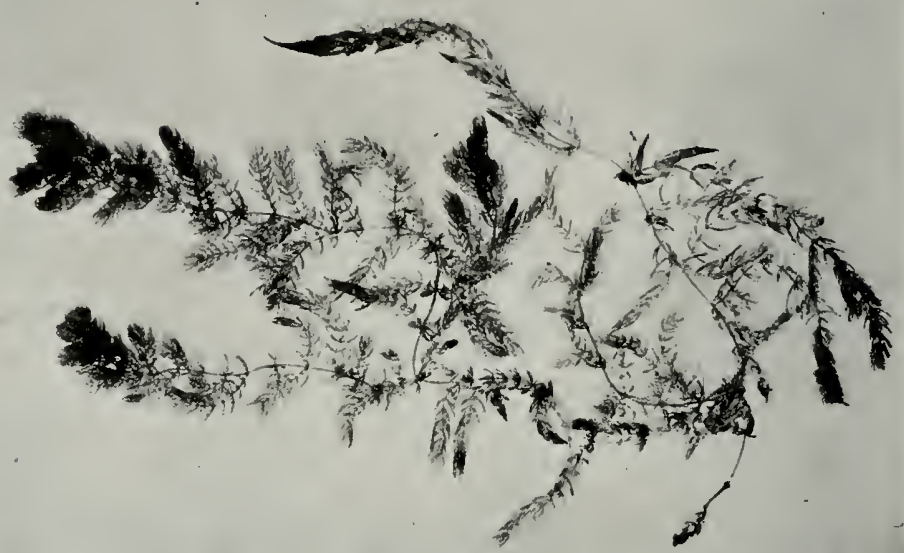

Fig. 21.-Coontail or hornwort (Ceratophyllum demersum), a favorite food of baldpates and gadwalls. It thrives in stable or semistable waters that are fairly clear and protected from waves.

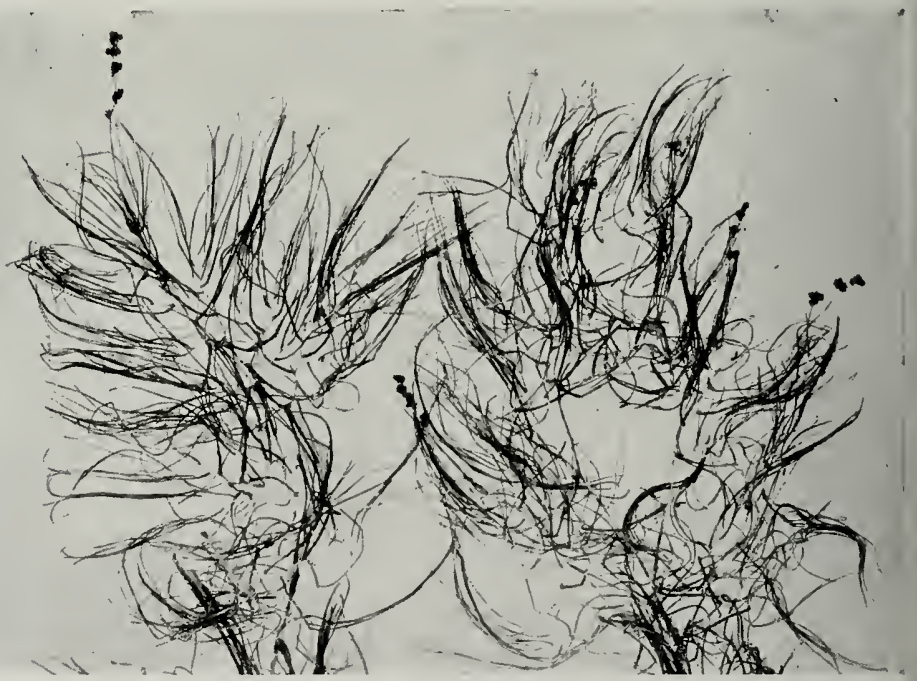

Fig. 22.-Sago pondweed (Potamogeton pectinalus). This plant grows best in lakes with stable water, at depths of 2 to 4 feet. It is colloquially called teal grass and eel grass. 


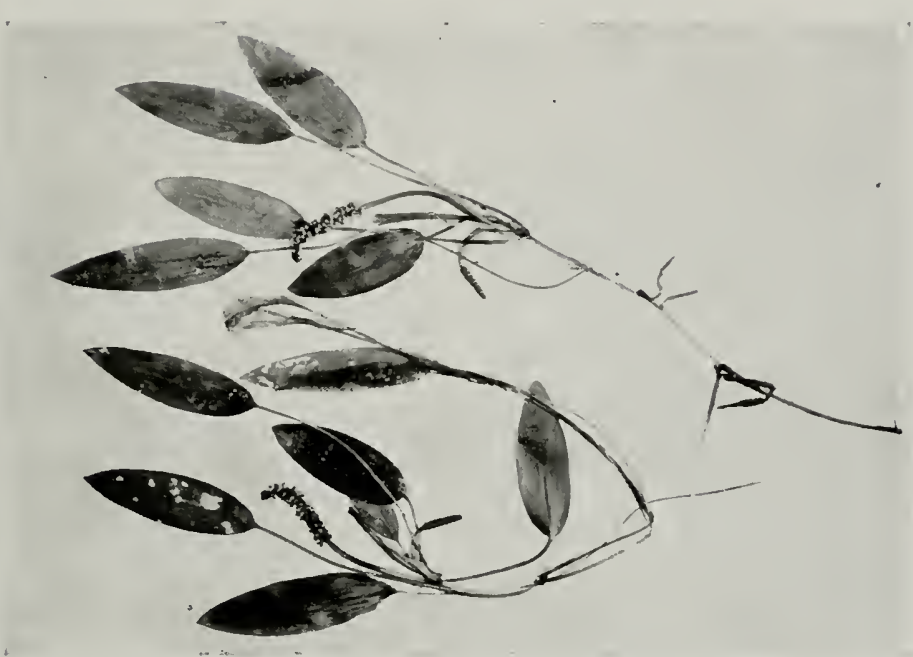

Fig. 23. - Longleaf pondweed (Potamogeton americanus), deer's tongue to most Illinois River residerts. Ducks teed on the seed of this plant.

pondweed has ceased to thrive in water over 48 inches deep, and it is entirely absent from water over 56 inches deep. However, in the glacial (Fox River) lakes, we have found it growing in 70 inches of water having a transparency of 54 inches.

Martin \& Uhler (1939) report longleaf pondweed growing at depths of 3 to

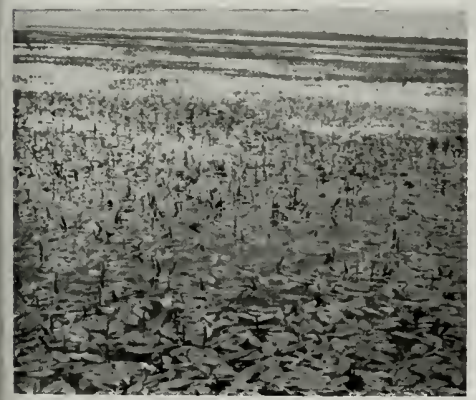

Fig. 24.--Longleaf pondweed beds at Lake Chautauqua, northeast of Havana. At Lake Chautauqua, where the water level is stable, extensive beds of this valuable duck food plant occur in water about 2 feet deep.
5 feet. Yet, at Lake Chautauqua, this species has not been found in water over 3 feet deep. In 1938, and to a lesser degree in other years, beds of longleaf pondweed extended through the lower lake on the spoilbanks of former drainage ditches, where the water was $S$ to 20 inches shallower than elsewhere. This apparent restriction on the maximum depth at which this pondweed will grow in Lake Chautauqua must be due to turbidity:

The increase of coontail at Beebe Lake from 34 acres in 1939 to over +18 acres in 1940, table 3, I feel certain must be attributed to the lower water during the latter rear. A transparency of 9 inches, combined with an arerage depth of 30 inches, apparently did not encourage dense growths of coontail in 1939. But the same transparency, with the water only 22 inches deep, permitted a greater light intensity to reach the plants, and was therefore more fatorable for the formation of dense heds in 1940.

\section{Other Factors in Plant Abundance}

In addition to turbidity and water depth, many other factors influence the 
abundance of aquatic plants. Among the most important are soil character, sedimentation and wave action.

Soils and Sedimentation. - The influence of soils on turbidity has been discussed. Soils in the Illinois River valley influence aquatic plants more by the extent to which they contribute to turbidity than by other properties they may or may not possess. The lake beds vary little in soil type. Beds in the upper portion of the valley are composed of Sawmill clay loam, while those in the middle part tend toward
Sawmill clay and Beaucoup clay loam. The lake basins of the lower part of the Illinois River region are made up of Sawmill clay plus Beaucoup clay. These soil types have a high fertility and are very productive.

The majority of bottomland lakes have large amounts of silt and clay particles deposited in their basins. During flood stages the river overflows its banks, thereby covering the bottomland and its lakes with a sheet of water containing a heavy load of soil. In the slowly moving back-

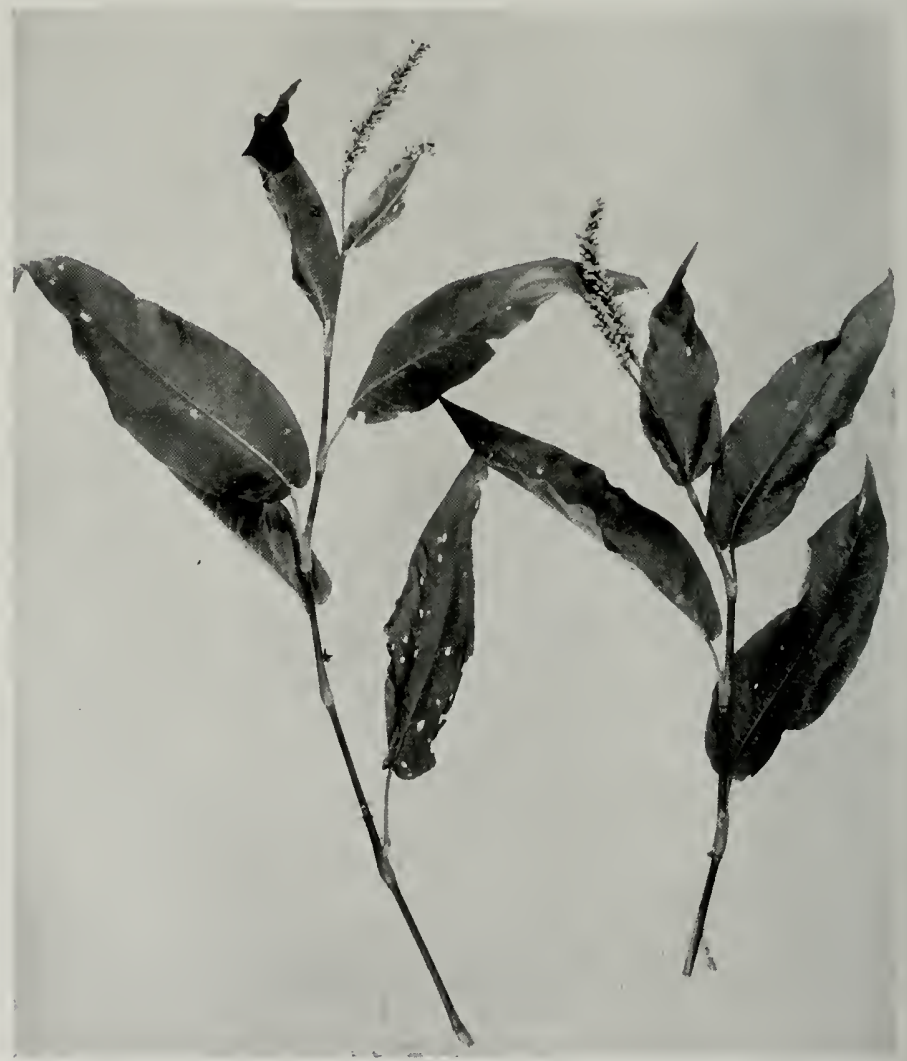

Fig. 25.-Marsh smartweed (Polygonum Muhlenbergii), red-top to most duck hunters because of its bright pink-red blossoms. When this plant grows in water 6 to 18 inches deep it produces seed, but when growing on dry ground it rarely produces either seed or flowers. 
waters, sand first settles from the water and, a few hours after the water becomes quiescent, silt particles commence to settle. It is sometimes a matter of days, however, before fine, suspended clay particles begin to settle from motionless water.

Streams that flow into bottomland lakes are another important source of sedimentation. In the past 5 years, Crane Lake has been filling up at a rapid rate because of the deposits from the channel waters of the Sangamon River. Several other lakes are in the same predicament. If nothing is done to check sedimentation, these lakes will continue to shrink in size, eventually becoming tangles of but tonbush, fig. 18 , willows and herbaceous vegetation of little use for waterfowl feeding or resting grounds.

Little can be done to prevent the dropping of sediment in fluviatile lakes during flood periods of the Illinois River, but it may be feasible to divert the course of streams entering these lakes so that they will deposit their loads elsewhere. At the Mallard Club, near Bureau, small dams are used during the hunting season to hold water from channels of Bureau Creek, which flows through the marsh. After the season, spillways are lowered so that the marsh is no longer a huge settling basin for the streams entering it. It is also possible to retard silting in some lakes by employing soil conserration measures on adjacent drainage areas.

Wave Action. - Influences of wind and wave action on aquatic plants through reducing transparency have been discussed. The direct effect of wave action in tearing and uprooting plants, because it is more apparent, is generally overemphasized in the Illinois River region. Occasionally, however, after severe wind storms, the shore of Lake Chautauqua is littered by coontail and sago and longleaf pondweed plants. During September, 1939. many wild celery plants were uprooted from beds in the Starved Rock pool. Occasionally wind has been known to blow down clumps of bur-reed and other marsh plants with an insecure footing.

Turbidity caused by waves may be alleviated on large bodies of water by the construction of islands and levees at right angles to the prevailing winds. These earthen structures should be planted with willow, buttonbush, marsh smartweed, river bulrush or hardstem bulrush in order further to reduce wave action and washing. Such areas furnish ideal shooting

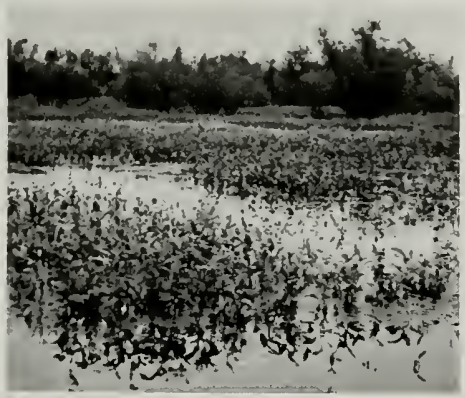

Fig. 26.-Typical marsh smartweed beds in water 12 inches deep at Lake Chautauqua, near Havana.

stands on large lakes where there is a paucity of these places.

Commercial Fishing. - Commercial fishing is an important industry in the 11linois River valley, where the bottomland lakes yield an abundant supply of carp, buffalo, catfish and sheepshead. These fish are caught largely with hoopnets and seines. Hoopnets have little effect on aquatic vegetation. Seines may, and frequently do, injure beginning plant beds by uprooting small patches of coontail and pondweeds or breaking off the growing tips of young plants.

\section{Seed Production}

Because seeds furnish the bulk of the plant food taken by ducks in the Illinois River valley, seed production is very important in determining the value of duck food plants.

We have made no quantitative measurement to date of seed production by various aquatic plants. Yet, from obserration, it is obvious that seed production of several aquatic plants varies tremendously. We know too little concerning the environmental complexities that govern seed production.

On numerous occasions I have examined beds of giant bur-reed. Of more than 30 such beds inspected, only 2 were producing an appreciable supply of seeds. One bed 


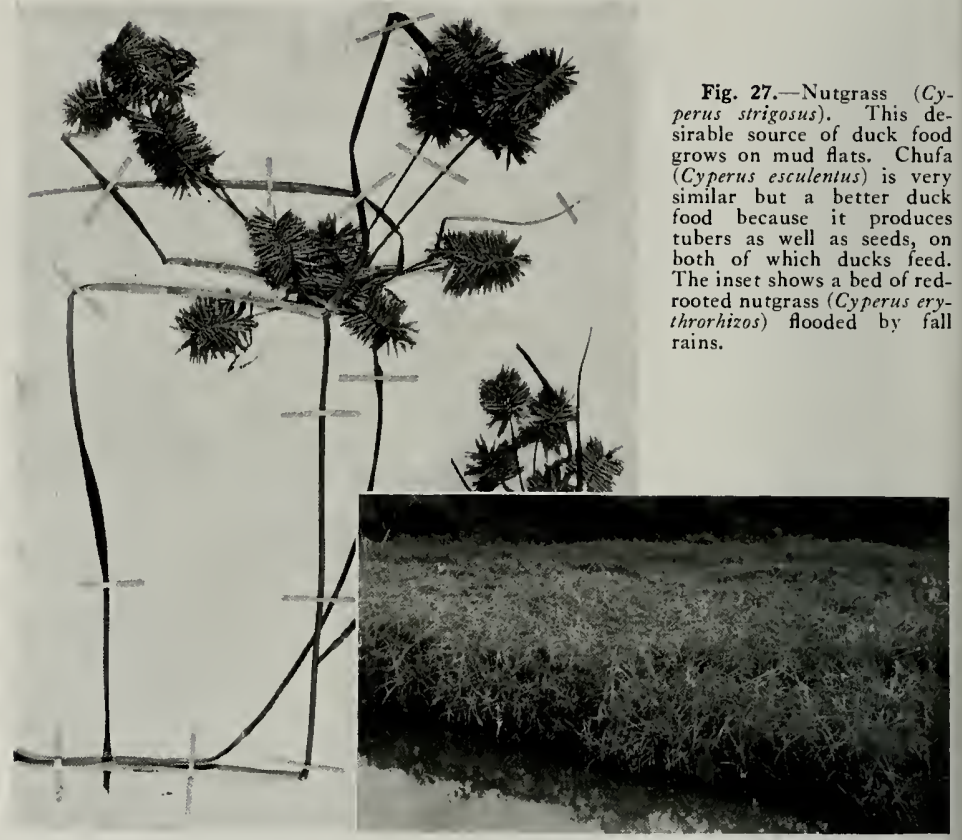

of 20 acres in Muscooten Bay had only one fruiting head per 16 linear feet in August, 1939. Two acres of giant burreed in Goose Pond in the same month had one fruiting head per 3 linear feet. The first bed was located in an area with more rapidly fluctuating waters than was the second.

Hutchens reports (letter, Jan. 8, 1941) that at McGinnis Slough in Cook County no seed was produced by giant bur-reed plants growing in water. Those growing on moist soil produced seed. The plants growing in water were 3 to 4 weeks later in development than those growing on moist soil.

Sago pondweed, fig. 22 , is an erratic seed producer in the Illinois River valley. Often rated as one of the most valuable duck food plants, it falls short of this reputation in the Illinois valley because of its failure to produce seed in certain years. ln 1938, inspection showed that longleaf pondweed beds in Lake Chautauqua, fig.
24 , were producing fully twice as much seed as were sago pondweed beds of equal size. A study involving use and abundance of duck foods (Bellrose \& Anderson 1940) corroborated this finding. Although at Lake Chautauqua sago pondweed produced more seed per plant in 1939 than in the previous year, the seed it produced in 1940 was approximately as much as in 1938. At Siebolt's and Sawmill lakes, sago pondweed produced little seed in 1940 notwithstanding the abundance of plants in those lakes, table 2. According to estimate, less than 0.5 per cent of the plants at these lakes, and at Goose Pond in 1940 only 2.0 per cent of the plants, had spikes bearing seed.

River bulrush, fig. 14 , is a notoriously poor seed producer. Despite the fact that it covers several thousand acres in the Illinois River valley, I have found only two small beds that were fruiting extensively. One was at Lake Chautauqua in 1938, and the other at Goose Pond in 1940. 
Stable waters may be conducive to fruiting, but such conditions do not insure it, since many beds in stabilized water areas have produced no seed. River bulrush propagates largely by rootstocks.
Much of the fruiting of marsh smartweed, figs. 25 and 26, is directly dependent on water depth. When growing in water 3 to 18 inches deep, this smartweed produces quantities of seeds, as observed at

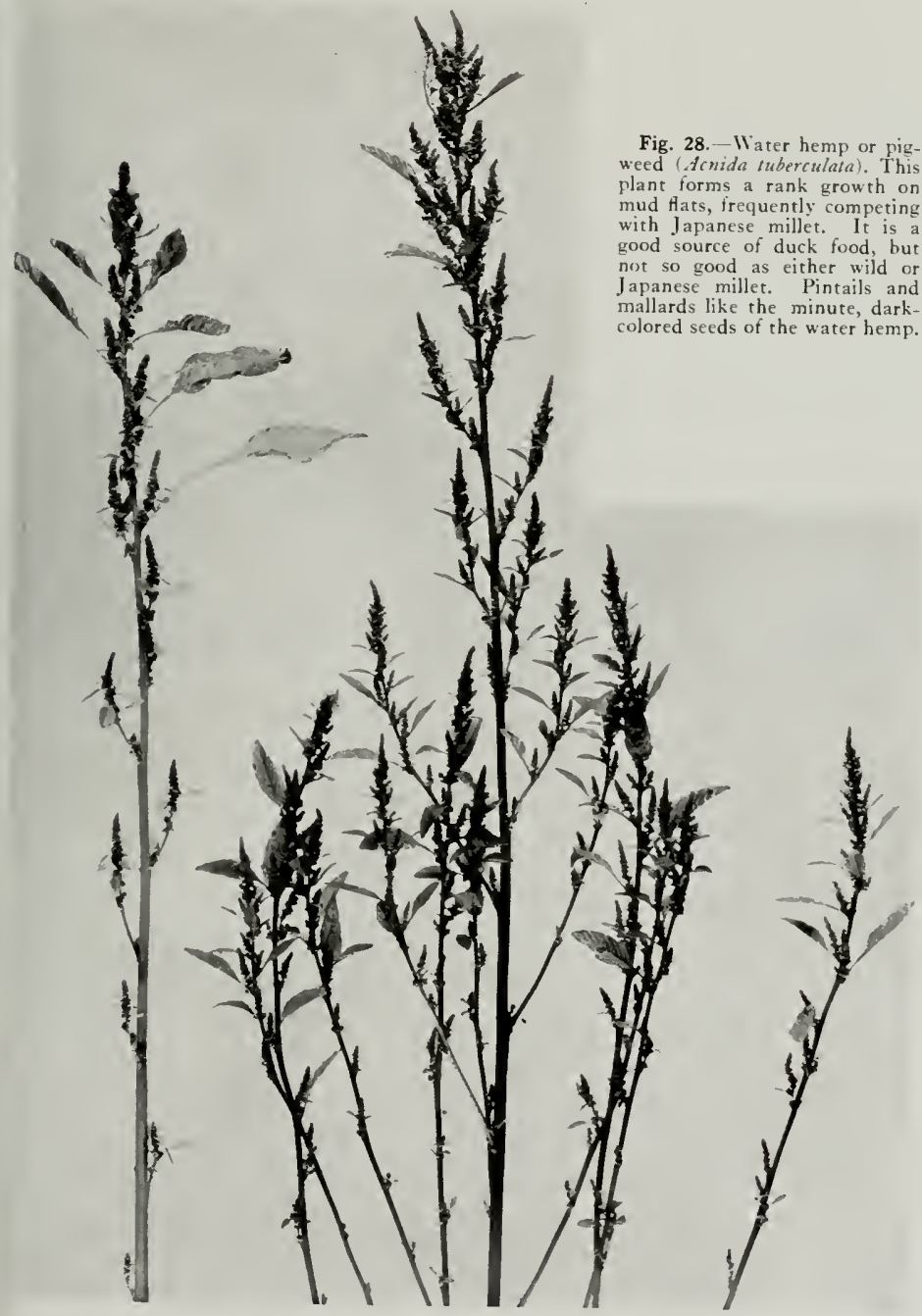


Lake Chautauqua in 1938, 1939 and $19+0$, at Jack Lake in 1938, at Cuba Island in 1938 and 1939, at Beebe Lake in 1938, and elsewhere. At Flat Lake, in 1938, a large bed of marsh smartweed fruited heavily in water $1+$ inches deep; in 1940 , the water depth had been increased to 36 inches, with the result that the smartweed was scattered, the plants sickly and the fruiting poor.

Numerous examples are known of marsh smartweed beds that failed to produce seed after the water had receded from the beds, leaving only moist soil. The beds at Jack Lake, fruiting heavily in 1938, were producing less than 1 per cent as much seed in 1940 , when they were exposed by receding water levels. At Beebe Lake, in 1938, almost every plant was pink blossomed; in 1939, little water remained in the marsh smartweed zone, and only a few flowering spikes were noticed. By 1940 , no water was left in the marsh smartweed zone, and scarcely a fruiting spike was found.

Observations alone are sufficient to show that moist-soil plants - wild millet, fig.
19, and Japanese millet, nutgrasses, fig. 27 , water hemp or pigweed, fig. 28 , smartweeds and rice cut-grass, fig. 29-produce more seed per unit of area than aquatic plants, such as longleaf and sago pondweeds, figs. 23,24 and 22 .

\section{Important Duck Food Plants}

To determine the value of duck food plants in the lllinois River valley, Bell rose \& Anderson (1940) compared the 1938 abundance and use of aquatic plants. Since numerous duck food plants, notably those in the moist-soil groups, were very scarce in 1938 because of high waters the value of all duck food plants was not ascertained. Compilation of the 1939 and $19+0$ data, when completed, should give an accurate index to the value of all important duck food plants in the Illinois River valley.

Essence of the report for 1938 was that rice cut-grass, figs. 29 and 30 , was the best native duck food plant in the lllinois River valley in that year, and that coontail, fig. 21, marsh smartweed, fig. 25, and longleaf pondweed, fig. 23, were

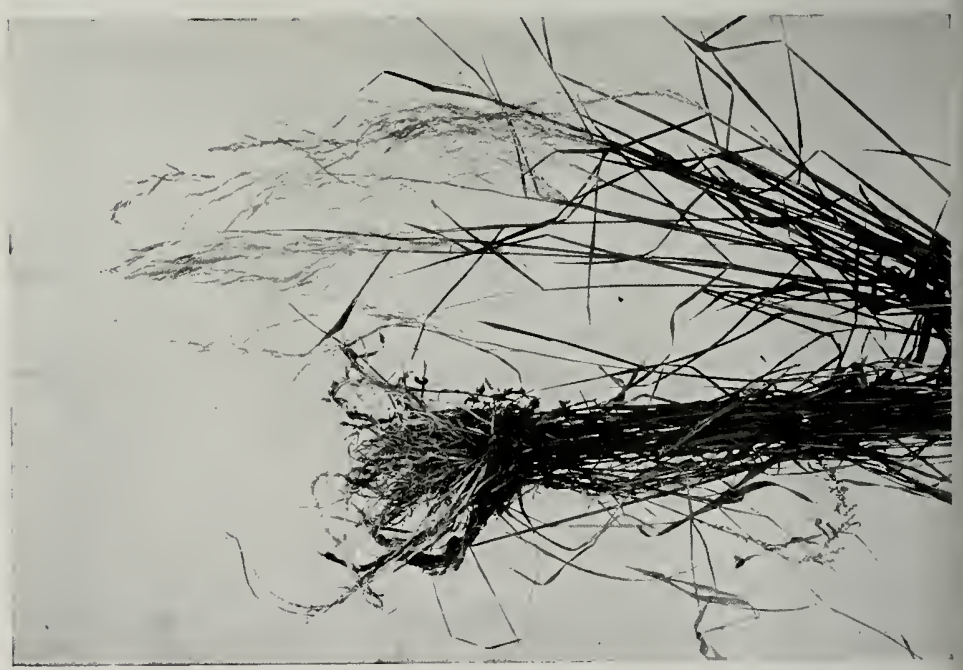

Fig. 29. - Rice cut-grass (Leersia oryzoides), better known in the Illinois River valley as sawgrass. It is one of the best native duck food plants, growing on moist soil and in shallow water. Ducks feed on the rootstocks and seeds. The plant pictured here is bent to show both ends. 
among the better plants. Giant bur-reed, duck potato, fig. 31 , and buttonbush, fig. 17 , rated as fair to poor sources of duck food. Sago pondweed, fig. 22, regarded usually as an excellent duck food plant, rated low in value in 1938 , probably because of the fact that it produced little seed locally. Spike rushes, river bulrush, fig. 14, and American lotus, fig. 13, were by Harry G. Anderson revealed not one trace of wild rice seed. When 1 risited Douglas Lake in August and September, 1939, thousands of red-winged blackbirds were congregated there, feeding upon the seed. They undoubtedly consumed most of the crop. Since there are only very limited areas suitable for the development of wild rice, it would seem that any plant-

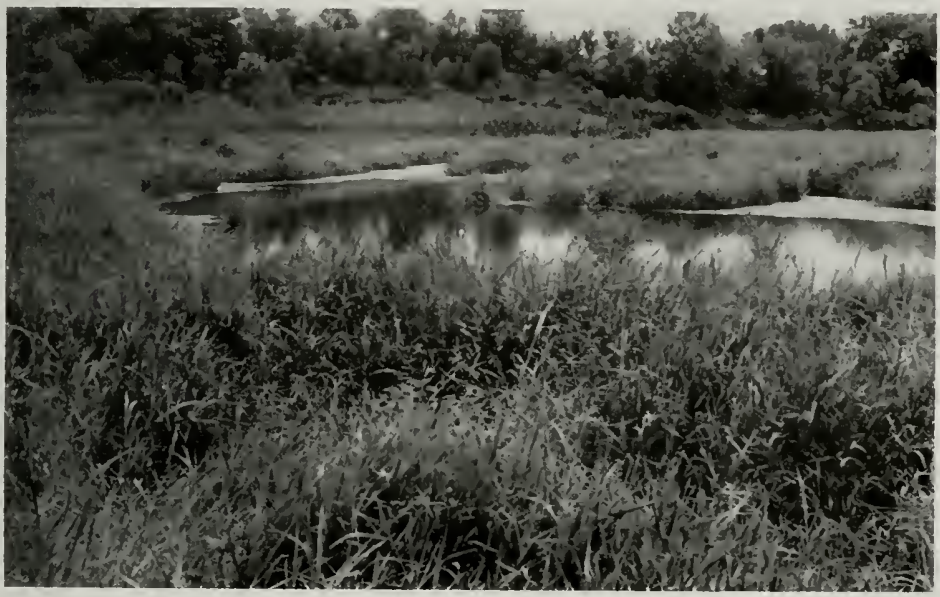

Fig. 30.- Rice cut-grass beds in Quiver Creek, near Lake Chautauqua, September, 1940.

found to he practically worthless as food for ducks in the lllinois River valley in 1938 .

Stomach analyses by Harry G. Anderson* of 1939 and 1940 gizzards, while not complete, indicate that rice cut-grass still ranks first. Marsh smartweed, coontail and buttonbush seem to have dropped in relative value. Wild millet, fig. 19, and Japanese millet, pigweed, fig. $2 S$, nutgrasses, fig. 27, and nodding smartweed appear to be among the top foods in these years, in which they were much more abundant than in 1938 .

IVild rice, generally a highly rated duck food, is apparently of little value as a duck food in the Illinois River valley. Although 81 acres of this species grew in Douglas Lake in 1939, 108 duck gizzards obtained there in the fall of that year and examined

* Working on Illinois Natural History Survey Federal Aid Project 2-R, referred to earlier in this paper. ings made-eren though successfulwould not produce much food for ducks in the lllinois River region; blackbirds would consume most of the seed.

\section{Plant Competition}

As already indicated, there are among the waterfowl food plants certain species that are little utilized for food by ducks. These species are often in direct competition with more beneficial watertowl food plants. Our studies have shown that despite their abundance in the Illinois River region. American lotus and river bulrush furnish little waterfowl food. Thes dominate most other forms of aquatic and marsh vegetation. In most places they must be considered weeds in the waterfowl habitat.

American lotus, fig. 13, which covers hundreds of acres with its broad oval 
leaves, has been seen to shade out beds of coontail and pondweeds. At Rice Lake, the decrease of coontail from 99 acres in

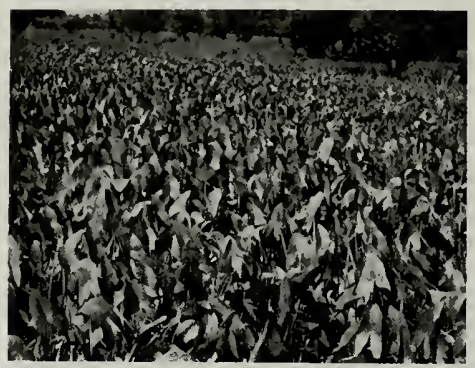

Fig. 31.-Duck potato (Sagittaria latifolia), a mediocre duck food, forms dense beds in shallow water and on moist soil. The seed is more important as a duck food than the tubers, which are usually too large and buried too deep to be of maximum availability to waterfowl.

1939 to 2.9 acres in 1940 must be attributed largely to the increase of lotus from $6+$ to over 317 acres in these same years, table 3. Nevertheless, lotus may, when it is not too dense, act as a nurse crop to coontail. Much of the +18.5 acres of coontail at Beebe Lake in 1940 was among open stands of lotus, while the 33.8 acres at Goose Pond were entirely among lotus. The increase of lotus at Lake Chautauqua from 6 to more than 207 acres in 3 years, table 1 , has been directly responsible for the loss of several sago and longleaf pondweed beds.

Lotus has continued to exist on mud flats during periods of low water, thereby frequently making inadvisable the sowing of Japanese millet and preventing the development of moist-soil plants on such habitats. A scattering stand of millet was obtained at the Central Illinois Club in 1939 and 1940 by broadcasting the seed among the lotus leaves. At Horn Lake, a sparse growth of millet was obtained where this method was tried in 1940; where lotus had been mowed before the seed was broadcast, dense beds of millet grew and thrived. Water hemp in 1940 assumed dominance over lotus at Crane and Horn lakes, where it completely crowded out several beds of the latter species.
River bulrush, fig. 1t, a coarse marsh species, has been found to be an important factor in restricting the growth of marsh smartweed at Beebe and Goose lakes, as well as at other lakes. It has also been observed to encroach upon giant bur-reed, softstem bulrush, duck potato, chufa, rice cut-grass and wild millet beds, all species more useful to waterfowl than river bulrush.

Buttonbush, figs. 17 and 18 , and willows tolerate long periods of inundation. In many lakes with fluctuating water levels, these species are encroaching upon such marsh plants as river bulrush, marsh smartweed and rice cut-grass. While our studies show that buttonbush furnishes fair duck food, willows are valueless as food. Both species cover many areas that could well be occupied by more desirable plants. However, willows have a place in the waterfowl habitat as cover and as a means of reducing wind action.

Certain species of green algae (Chlorophyceae) have destroyed submerged and floating plants on Lake Chautauqua and one or two other lakes. These algae in 1938 and 1939 formed dense mats over beds of sago and longleaf pondweeds and coontail, thereby excluding a large amount of sunlight from those plants. We do not know whether the pale, sickly appearance assumed by many pondweed beds at that time is the result of blanketing by algae or whether it is due to some other cause. During 1940, algae blown by the wind so matted some marsh smartweed beds of Lake Chautauqua as apparently to cause considerable loss of vigor in the smartweed plants. Martin \& Uhler (1939) report that certain blue-green algae appeared upon decomposition to secrete a toxic substance that affected submerged seed plants. Possibly marsh smartweed, an emergent species, was affected by a toxin released by the algae.

\section{Methods of Control}

There are several methods by which American lotus, river bulrush and other weeds may be partially if not entirely controlled. They are (1) by altering existing water levels, (2) by cutting and (3) by using chemicals.

River bulrush may be partially if not entirely controlled by raising the waters of its 
lake or marsh habitat. Although an increase of a few inches in the water level does not injure the river bulrush, it cannot tolerate water 20 or more inches deep during the growing period. At Lake Chautauqua, because of stabilized waters 10 to 18 inches deep, river bulrush has since 1938 become less abundant each year. Marsh smartweed, figs. 25 and 26, and plants should be cut just before the Howering period, before the plants produce seed. With lotus, flowering does not usually occur before July, and it is believed that by that time the plant has stored sufficient energy to produce quickly new leaves and flower stalks. Experiments are now being conducted by Homer Bradley on Lake Chautauqua to determine if sev-

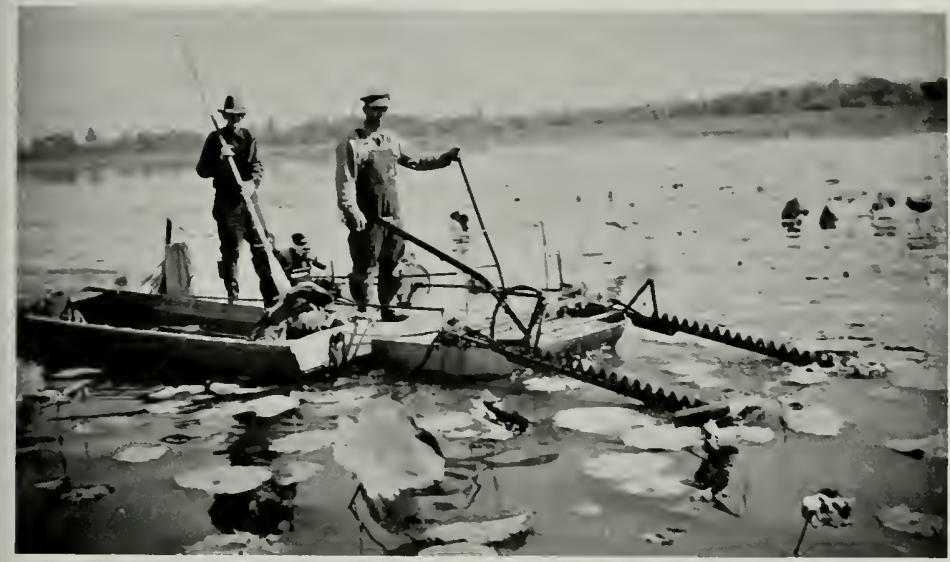

Fig. 32.- Machine for mowing aquatic plants. At the Lake Chautauqua National Wildlife Refuge, where this machine is shown in operation, it was possible to mow an acre of American lotus per hour.

duck potato, figs, 16 and 31 , occupy areas formerly held by river bulrush.

We believe that the American lotus can readily he drowned by flooding the plants during the flowering period. In 1927. American lotus was extirpated from many sections of the lllinois valley by a summerlong flood. Buttonbush and willows also are controlled by flooding, but it is necessary to inundate these species for over a year. Cattail, marsh cordgrass, cane (Phraymites communis) and water willow (Decodon verticillntus), all marsh plants, are also readily controlled by inundation.

It is necessary to cut herbaceous aquatic plants over an extended period to eradicate the beds completely. Mowing at least twice per year for 2 or more years is necessary for such species as cattails, river bulrush and American lotus. With the possible exception of American lotus. eral mowings, beginning in June and repeated at intervals throughout the summer, will control lotus more successfully than mowings made only before flowering occurs.

Mowing with a scythe may successfully remove patches of river bulrush, cattail, lotus and other marsh species. Several duck clubs have found it practical to remove lotus from mud flats and shallow water areas with scrthes. At the Crane Lake Club, an average of 1 man-day was necessary to mow, by hand, 1 acre of lotus growing on moist soil.

A mechanical underwater weed cutter that can be purchased, fig. 32, consists of a sickle attachment operated by a small motor, mounted on the bow of a shallowdraft boat. At the Crystal Lake Club, across the Mississippi River from Burlington, Lowa, and at Lake Chautauqua, this mower has been used successfully to cut 
American lotus. Under favorable working conditions, 1 acre of lotus was cut per hour. Mowing lotus with the mechanical weed cutter before leaves and flower stalks are extended above the water surface would result in faster mowing and would lessen trouble caused by vegetation piling up beneath the boat, but might necessitate three or four mowings per year.

Frederic Leopold reports that, at Crystal Lake, lotus beds mowed once in 1939 and twice in 1940 were reduced in size and much less dense in 1941 than check beds that had not been cut.

Several chemical sprays and dusts have been used in an attempt to control various aquatic and marsh weeds. At Crystal Lake, Frederic Leopold and Arthur Hawkins experimented with the use of copper sulfate and sodium chloride in the control of river bulrush. Only copper sulfate appeared to have any effect on this species. The chemical caused some loss of vigor in the plants, but did not materially retard their growth.

Martin \& Uhler (1939) experimented with various chemicals on water chestnut and other worthless marsh plants on the Potomac River in 1935 and 1936, using chemicals in solution applied with a pressure sprayer and, where possible, also in the form of dusts. Chemicals they experimented with were sodium chlorate, sodium arsenite, sodium chloride, copper sulfate, iron sulfate, zinc chloride, ammonium thiocyanate, calcium oxide and a commercial herbicide.

They found that the most effective kill was obtained on calm, hot days of bright sunshine, and the best solution consisted of 1 pound of dry, powdered sodium arsenite and one-half pound of sodium chlorate dissolved in 1 gallon of water and sprayed over an area of 150 square feet of plant growth. River bulrush they controlled fairly well by a solution of ammonium thiocyanate: $11 / 2$ pounds of that chemical in 1 gallon of water applied to 150 square feet of marsh. They sprayed chemical solutions by means of t-gallon, hand-operated sprayers capable of developing a pressure of 90 pounds.

At the present time chemical control of aquatic and marsh weeds is in the experimental stage. It is too expensive to use over extensive areas, results are uncertain and many of the chemicals used are dangerous not only to wildlife and fish but also to man.

\section{Natural Propagation}

Aquatic and marsh plants frequently make their appearance in newly created or altered habitats by natural methods of dispersal. Seeds and other propagative parts are carried by water, ducks and other water birds. Evidence indicates that seeds of certain plants may be deposited and remain viable on a lake bottom for several years, not germinating until suitable growth conditions prevail.

With increased stabilization of water, 5 acres of sago pondweed appeared at Sawmill Lake in 1939 and increased to over 115 acres in 1940, table 2. So far as is known, no plantings of sago pondweed were made there. Evidently because of improved environment, wild rice appeared in 1939 over 81 acres at Douglas Lake, where it had been absent for a number of years. Wild rice appeared in 1939 at Rice and Beebe lakes without being planted, table 3 .

The rapidity with which most moist-soil plants appear by natural propagation when conditions become suitable is indicated in table 5. The occurrence of over 141 acres of water hemp and 79 acres of nutgrasses at Crane Lake, and 153 acres of nodding smartweed, over 84 acres of nutgrasses and nearly 931 acres of water hemp at Clear Lake is noteworthy in this respect. Wild millet has appeared with planted Japanese millet at these lakes. The nearly 50 acres of millet at Quiver Lake in 1940 came probably from seeds deposited by plants growing there in 1936 and 1937.

In 1937 and 1938, Gilbert Lake and sloughs near the mouth of the Illinois River were barren of plants except for chufa. Nearby Flat Lake contained, during the summer of 1938, scattered patches of water dock (Rumex altissimus), water plantain (Alisma Plantago-aquatica) and marsh cord grass.

In the summer of 1938, after the Alton navigation dam on the Mississippi River had been placed in operation these Illinois valley areas were flooded. Since then the pool level has been fairly constant during the summer season. By July, 19+0, the 
forest-lined sloughs were carpeted by greater and lesser duckweed, and they also supported extensive beds of mud plantain, coontail and sago pondweed. A few beds of longleaf pondweed, creeping water primrose, bladderwort, marsh smartweed and cattail were also growing there.

In July, 1940, extensive areas of Gilbert Lake were covered by longleaf pondweed. Scattered beds of mud plantain, coontail, American lotus, duck potato, water primrose, river bulrush and cattail occurred. In 1938, none of these species had been seen there.

Marsh smartweed appeared at Flat Lake in 1939, forming a bed of some 20 acres. In July, 1940, parts of this bed had died, apparently because of the deep water. Scattered patches of coontail and longleaf and sago pondweeds also dotted the lake.

A pond at the Crystal Lake Club apparently contained no vegetation in 1939. Lack of vegetation seemed to be due to high turbidity created by rough fish. Removal of the fish cleared the water in $19+0$. An abundance of muskgrass and leafy pondweed shortly afterward covered the area. No plantings of these species had been made.

No submerged and only a few emergent aquatic plants occurred in McGinnis Slough, Cook County, in 1939. When environmental conditions improved in 1940 , approximately 28 acres of giant bur-reed. and over $1+t$ acres of muskgrass, coontail and leafy pondweed appeared in the slough. No plantings of these species had been made.

From this evidence it appears that the sowing of duck food plants is not always essential to the establishment of waterfowl feeding grounds, for frequently the plants become established by natural means, upon the creation of a suitable environment. The planting of duck food plants is often adrisable, however, to speed development of natural food resources and to insure valuable species a start against competing weed species.

\section{Management Recommendations}

For many rears, duck clubs along the 1 llinois River have been attempting to improve the waterfowl habitat by planting numerous species of aquatic and marsh plants. Most of these plantings have been made with little regard for enrironmental conditions. Reports received from 31 representative duck clubs in the valley show that all but three of these clubs have planted waterfowl food plants of some sort in recent years.

Table 10 summarizes the results of waterfowl food plantings made by 28 duck clubs in the lllinois valley. 'Thirty-four plantings failed, while 22 plantings were at least partially successful. Japanese millet plantings were more successful than those of any other species; fair results were secured from duck potato plantings.

Since 193t, thousands of dollars have been spent by lllinois valley duck clubs for aquatic plant propagating material. In 1939,12 clubs reported that in the previous 3 rears they had spent more than $\$ 970$ on planting stock and more than $\$ 320$ on labor employed to sow it. Sixteen other clubs, of 26 answering a questionnaire sent out in $19+0$, reported that they had spent $\$ 1.760$ for duck food plantings in 1939. Three duck clubs spent $\$ 1,050$ for coontail, sago pondweed and several other

Table 10.- Results of waterfowl food plantings made by 28 duck clubs in the Illinois River valley in recent years.

\begin{tabular}{|c|c|c|c|}
\hline SPECIES & $\begin{array}{c}\text { 1) YCK CLIBS } \\
\text { UTHLIZNG }\end{array}$ & $\begin{array}{c}\text { Duck Clubs } \\
\text { Reporting Siccess }\end{array}$ & $\begin{array}{c}\text { Duck Clubs } \\
\text { Reporting Failure }\end{array}$ \\
\hline 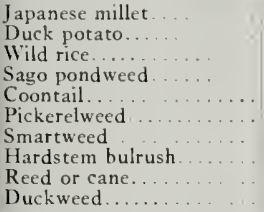 & $\begin{array}{r}22 \\
9 \\
8 \\
5 \\
5 \\
2 \\
2 \\
1 \\
1 \\
1\end{array}$ & $\begin{array}{r}12 \\
4 \\
\frac{1}{1} \\
1 \\
0 \\
1 \\
1 \\
0 \\
0\end{array}$ & $\begin{array}{r}10 \\
5 \\
6 \\
4 \\
4 \\
2 \\
1 \\
0 \\
1 \\
1\end{array}$ \\
\hline
\end{tabular}


plants in the spring and early summer of 1940. When I inspected these plantings in August and September of the same year, only fragmentary and unsatisfactory results were apparent. In one duck club pond, $\$ 200$ worth of coontail had been dumped, upon the recommendation of a specialist from an aquatic nursery. There was not a trace of coontail left when $l$ inspected the area 3 months later. High turbidity and shallow water undoubtedly were responsible for its disappearance.

Field inspection indicates that widespread failure of aquatic plantings cannot necessarily be charged to poor stock but rather may often be caused by planting species where conditions are not suitable for their survival or by planting stock that is not indigenous to the region. Existing plants and environmental conditions should be noted, and species known to grow under similar conditions should be used. It must be remembered that, if a habitat becomes suitable for a particular species, that plant usually appears through natural dissemination of propagative parts.

What, then, can be done to improve waterfowl feeding grounds? Evidence presented heretofore in this paper indicates that improvement of the area by controlling water levels is the best attack. In the Illinois River valley there are two methods of controlling the water levels and thereby managing the habitat. Which method is to be followed must necessarily depend upon prevailing conditions in the area under consideration. Whether the level of drainage of the river is above or below the lake basin is of primary importance in determining the method to be used.

Method A.- The type of habitat resulting from the first method furnishes more food per unit area and attracts larger numbers of mallards and pintails than other types of habitats. It is, therefore, the optimum waterfowl habitat in the Illinois River valley.

The water levels should be lowered sufficiently by July 1 to leave at least 30 per cent of the area in mud flats, allowing such moist-soil plants as nutgrasses, water hemp or pigweed, various smartweeds, teal grass, wild and Japanese millets and rice cut-grass-all good duck food plants-to develop on the mud flats. These plants usually appear by natural means, without the necessity of sowing. However, if they have not occurred on the grounds in a number of years, it is advisable to sow the mud Hats with Japanese millet seed and tubers of chufa. Chufa might well replace other less valuable nutgrasses, which pro-

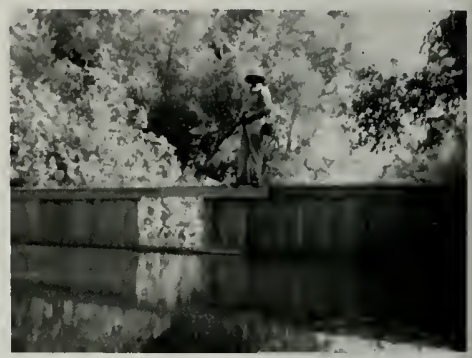

Fig. 33.-Small dam constructed at outlet of lake. The lake shown here is fed by springs; closing of the gate in the hunting season will flood the area.

duce no tubers and which are the more abundant of the species in the lllinois River valley.

In order to make the seeds, tubers or rootstocks of the moist-soil plants available to waterfowl, it is necessary to flood the beds in the fall months. Springs, streams, pumps and natural rises in the Illinois River are used in conjunction with dams, fig. 33, and levees to flood such areas. Fig. 2 shows that over a period of 20 years there is a trend toward a rise in the Illinois River waters during these months.

Management method A was used successfully in $19+0$ at Horn Lake, Clear Lake and Bath Lake. It is generally applicable to that region below the Peoria dam as far as Treadway Lake, near Browning, and to the Meredosia Bay region, near Meredosia.

Method B. - The type of habitat resulting from the second method is more attractive to diving ducks, baldpates and gadwalls than the first type.

Water levels should be maintained as nearly constant as possible at a depth of 2 to 3 feet. This creates a habitat suitable for such submerged and floating aquatic plants as longleaf, sago and bushy pondweeds and coontail. As a result of the water level created by the Peoria navigation dam, bodies of water between Peoria 
and Henry appear to be best adapted to this type of management.

\section{Tolerant Food Plants}

Where little can be done to improve the physical condition of a bottomland lake through stabilization or control of the water level, the only remaining alternative is to encourage vegetation that is tolerant of such an environment. 'The following plants have the ability to grow under conditions resulting from irregular fluctuations, and among them are a few important waterfowl food species which should be considered in a program to improve habitats through planting: giant bur-reed, duck potato, arrowleaf, rice cut-grass, wild millet, Japanese millet, teal grass, marsh smartweed, swamp smartweed, nodding smartweed, chufa, creeping water primrose and water hemp or pigweed. Giant hur-reed, duck potato, arrowleaf, rice cutgrass, marsh smartweed, swamp smartweed and creeping water primrose grow in shallow water (averiging less than 1 foot) and on mud thats and banks. Japanese and wild millets, teal grass, chufa, nodding smartweed and water hemp grow on moist to fairly dry soils.

As determined from examinations of duck gizzards by Harry Anderson * and by Martin \& Uhier (1939), rice cut-grass, wild millet, Japanese millet, marsh smartweed and chufa are among the most val-

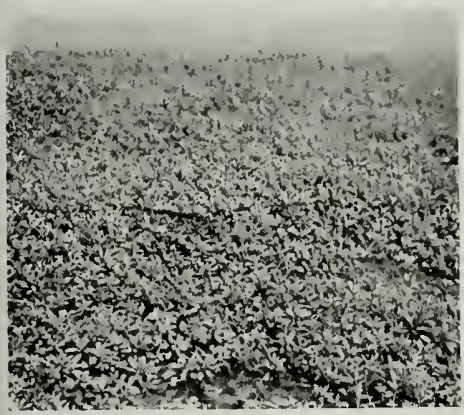

Fig. 34.-Creeping water primrose Y Yussibea diffusa). Small areas of this plant occur near Havana and near the mouth of the Illinois River. A fair duck food, this southern plant may prove to be valuable in certain areas that lack first class duck foods. uable waterfowl food plants in the Illinois and Mississippi river valleys.

Before $19+0$, creeping water primrose, fig. 34 , had been found as far north as

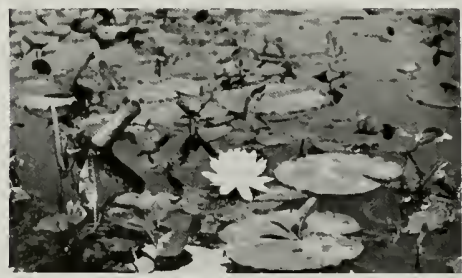

Fig. 35. - White water lily (Castalia tuberosa) is a slightly better duck food than American lotus, from which it can be distinguished by its cleft leaves.

Gilbert Lake and sloughs near the Illinois River mouth. In 1940 , I observed several heds in Lake Chantauqua, the first such record for this lake. Several bushels of water primrose plants were transplanted in July to lakes near Havana which have fluctuating water levels. They were planted on mud flats and in shallow water, and despite a 20 -inch rise in water levels the plantings were thriving in Octoher.

In regard to the value of creeping water primrose, Francis M. Uhler (letter, Jan. 22, $19+1$ ) states: "I have considered it a third-grade duck food, in about the same class as the white water lily (fig. 35), pickerelweed and the arrowheads. In the region centering around Arkansas, mallards, ring-necked ducks, baldpates, blue-winged teal and wood ducks have heen found to feed on water primrose seeds in fair quantities, sometimes eating thousands of seeds. A mallard contained more than 100,000 seeds of a Jussiaen that was not identified to species.'

On the question of planting water primrose, Mr. Uhler states: "In areas like the lllinois River valley, where first-class duck foods are scarce hecause of fluctuating water levels, I would favor planting it in those areas where the better food plants cannot thrive, for it can tolerate irregular fluctuations in water levels that would destroy most of the truly aquatic plants.'

In the propagation of aquatic and marsh plants, various parts are employed.

* Working on Illinois Natural History Survey Fed eral Aid Project 2-R, referred to earlier in this paper. 
Some kinds develop best from seeds, others from tubers, rootstocks, cuttings or entire plants. Time, method, cost and ease of planting are factors to be considered in selecting the types of propagating material. Smartweed seeds, for instance, are usually low in germination unless scarified or stored under conditions approaching natural freezing and thawing of winter. Pondweeds readily develop from cuttings, transplants and seeds. Japanese millet seed is inexpensive, easily sown and produces good results when natural conditions are favorable. Table 11 lists the parts of a number of waterfowl food plants most desirable to use in planting. Data on propagative parts have been adapted largely from McAtee (1939) and Martin \& Uhler (1939).

Japanese millet and chufa are best sown on mud flats left exposed by receding waters. Such flats usually occur, as shown in fig. 2, in July and August. In the Illinois River valley, in order to assure maturity, this millet and chufa should be planted previous to July 15. Plantings made as late as Aug. 1, however, will occasionally mature before frost. Because of the low germination rate of dry-stored smartweed seeds, these seeds should usually be sown in the fall, unless stored as previously mentioned.

Other species of aquatic and marsh plants may be planted in the spring or fall months. Where there are large concentrations of waterfowl during the autumn, however, there is danger that the propagative material may be consumed by them. Planting in early spring is often unwise because of the erratic water levels created by high water, usually prevalent at that time. For most aquatic species, the latter part of May and the first part of June constitute the best planting period. By this time the migrating waterfowl have departed, the spring floods are usually subsiding, and yet the plantings should have sufficient time to mature before frost.

\section{Methods of Planting}

Seeds of Japanese millet and smartweeds are easily broadcast over mud flats. Smartweed seeds may be broadcast in shallow water that will later recede, leaving exposed mud flats. Water-saturated seeds of most aquatic plants, such as the pondweeds, will usually sink. If they Hoat, they should be embedded in small clay balls and these dropped in water of the correct depth. With softstem and hardstem bulrushes, which are good duck food plants not to be confused with river bulrush, greater success has resulted from broadcasting the soaked seeds upon the moist soil along the edge of the water than from sowing them in shallow water. A bushel of seeds of these plants is sufficient to cover 1 acre.

Tubers of sago pondweed and white water lily are easily planted by embedding one or two tubers in a clay ball and dropping the balls overboard from a boat in the desired place. Rootstocks of giant burreed, spikerush, bulrushes, pickerelweed and marsh smartweed are easily planted by hand, the operator wading into the shallow water and embedding the rootstocks in the soft mud. Where the soil is hard, a hoe or spade may be found necessary to dig a pocket. Tubers of chufa may be broadcast on mud flats that are dragged or raked afterwards, or they may be planted to a depth of 1 or 2 inches by hand. About one bushel of chufa tubers is required for each acre to be planted, while 1,000 to 1,200 tubers and rootstocks of other aquatic and marsh plants are sufficient to sow 1 acre.

Leafy cuttings of the pondweeds grow successfully if short sections of the stem containing two or three nodes are covered by 1 inch of soil. They may be planted by hand in water up to 30 inches in depth, or in deeper water by first forming a ball of mud around several cuttings. The balls then should be dropped from a boat at the rate of about one per 2 square yards.

Lynn Hutchens and I planted several species of aquatic plants in early August, 1940, in the newly created Skokie Lagoons of Cook County. Most of the transplant material was gathered at Fox Lake. Approximately 2,500 longleaf pondweed plants, 4,000 muskgrass "tufts," 100 creeping water primrose plants and over 1,000 each of hardstem bulrush and giant bur-reed plants were used. When I inspected the Skokie Lagoons on July 21, 1941, I found dense longleaf pondweed beds around the margins of the lagoons where the plantings were made. I found only a few clumps of muskgrass and only two patches of creeping water primrose. 
Perhaps due to bank washing, less than 10 per cent of the hardstem bulrush and giant bur-reed plants had survived, and no spread had occurred from these.

Dr. Lee E. Yeager of the Illinois Nat- tural History Survey successfully transplanted a number of emergent species in 1940. In this instance, 1,500 duck potato transplants showed a survival of over 95 per cent, while both hardstem and soft-

Table 11.-Aquatic plants, with parts most suited for propagation, and optimum planting conditions.

\begin{tabular}{cc} 
Species of Plant & Propagating Parts \\
\hline
\end{tabular}

Giant bur-reed Sparganium eurycarpum

Sago pondweed Potamogeton pectinatus

Longleaif pondweed Potamogeton americanus

Bushy pondweed tiajas guadalupensis

Duck potato Sagitharia latifolia

Arrowleat

Lophotocarpus calycinus

Whaterweeds Anacharis sp.

Wild celery

Vallisneria spiralis

Rice cut-grass

Leersia oryzoides

Wild rice

Zizania aquatica

Japanese millet

Echinochloa frumentacea

Chuia

Cyperus esculentus

Spike rushes

Eleocharis sp.

Common three-square

Scirpus americanus

Softstem bulrush Scirpus validus

Hardstem bulrush Scirpus acutus

River bulrush Scirpus fluviatilis

Greater duckweed Spiradela polyrhiza

Pickerelweed

Pontederia cordata

IIarsh smartweed

Polygonum. Wuhlenbergii

Swamp smartweed Polygonum hydropiperoides

Nodding smartweed Polygonum lapathifolium

Largeseed smartweed Polygonum pennsylvanicum Coontail

Ceratophyllum demersum

American lotus

Velumbo lusea

White water lily

Castalia tuberoso

Creeping water primrose Fussiaea diffusa

Buttonbush Cephalanthus occidentalis
Rootstocks, entire plants, seeds

Entire plants, tubers, leafy cuttings, seeds

Entire plants, leafy cuttings, seeds

Leafy cuttings, entire plants

Tubers, entire plants, seeds

Entire plants, seeds

Masses of plants

IVinter buds, rootstocks, sceds

Rootstocks, entire plants, seeds

Seeds

Seeds

Tubers, transplants

Rootstocks, entire plants

Entire plants, rootstocks, seeds

Entire plants, rootstocks, seeds

Entire plants, rootstocks, seeds

Entire plants, rootstocks, woody tubers

Masses of plants

Rootstocks, entire plants

Rootstocks, entire plants

Entire plants, seeds

Seeds, transplants

Seeds, transplants

Masses of plants

Rootstocks, seeds

Tubers

Entire plants, roots, seeds

Cuttings, transplants
Moist soil to 12 inches

2 to 4 feet

18 inches to 3 feet

18 inches to 40 inches

Moist soil to 18 inches

Moist soil to 18 inches

2 to 6 feet

30 inches to 5 feet

Moist soil to 6 inches

1 to 3 feet

Moist soil

Fairly dry to moist soil

Moist soil

Moist soil to 6 inches

Moist soil to 12 inches

Moist soil to 20 inches

Moist soil to 12 inches

Broadcast on water surface

3 inches to 14 inches

Moist soil to 18 inches

Moist soil to 8 inches

Fairly dry to moist soif

Moist soil

2 to 5 feet

20 inches to 40 inches

28 inches to 40 inches

Moist soil to 3 feet (in protected areas)

Moist soil to 6 inches 
stem bulrush and white water lily, aggregating over 3,000 plants, showed an average survival of about 90 per cent. This planting was made about mid June on Lake Glendale, an 80 -acre artificial lake flooded only 3 months previously, in the Shawnee National Forest in Illinois.

Dr. Yeager used the entire plants, with as little disturbance to the roots as possible. The duck potato stock averaged about 6 inches high. Care was taken in digging to avoid disturbing the soil about the roots or dislodging the tuber. The plants were transported by truck to the planting site, 2 miles distant, and set within a few hours after being dug. Planting was in moist soil and in shallow water, and consisted merely of setting each duck potato clump in a hole roughly cut to fit, followed by light firming with the foot. In August, 2 months later, these plants averaged nearly 2 feet in height, and in addition, each had given rise to an average of about five other plants.

The softstem and hardstem bulrushes were lifted as "sod" clumps; and the water lily stock consisted of 8- to 10 -inch lengths of the large, fleshy roots. The lilies were buried in the bottom soil; the bulrushes were planted in the moist soil along the shore. The water lily stock was leafclipped, although this operation may not have been necessary. Hardstem bulrush transplanted in June matured seed later in the season.

Fragments of the growing branches of coontail and waterweed readily grow into entire plants. While fragments or masses of these plants may by themselves become attached to the bottom after being placed in the water, it is advisable to anchor some plants to the bottom. Such attachment prevents the plantings from being washed ashore or displaced by wind. An oar or forked stick is often satisfactory in anchoring masses of these plants to the bottom. About 8 bushels of these species are necessary to plant 1 acre.

At Lake Chautauqua National Wildlife Refuge, the placing of willow and buttonbush cuttings in moist soil readily resulted in growth. There was an exceptionally high success of the buttonbush cuttings. Failure of a number of plots was due to wave washing and to flooding.

The depths best suited for propagating aquatic and marsh plants in the Illinois
River valley are given in table 11 . The figures are based on depths at which the plants were found growing in the bottomland lakes. Only the normal depth range of the plants is listed. Abnormal variance created by drought or floods is not given. For example, American lotus often exists on mud flats in midsummer, and grows in 10 feet of water during the spring. River bulrush and marsh smartweed have been observed living for short periods in water t or more feet in depth ; longleaf pondweed has existed, temporarily, on mud flats.

\section{Summary}

1. The major waterfowl habitat in Illinois extends along the Illinois River for 140 miles, coinciding with the distribution of bottomland lakes.

2. The water levels of the river and the connecting bottomland lakes customarily fluctuate greatly with the season. Recently navigation dams have stabilized water levels in many lakes.

3. At other lakes, natural and artificial levees stabilize and control water levels.

t. With respect to water levels, the bottomland lakes lying adjacent to the Illinois River may be grouped into three classes: stable, semistable and fluctuating.

5. Abundance of aquatic plants in various lakes of the Illinois River valley was determined by plotting the vegetation beds on base maps and measuring the areas by means of a planimeter.

6. A comprehensive survey of plant species in 1938, 1939 and 1940 in more than 20 lakes in the Illinois River valley revealed that sago and longleaf pondweeds, coontail and marsh smartweeds predominated at lakes with stable water levels. River bulrush, American lotus and coontail topped the list in semistable lakes. In lakes with fluctuating waters, only river bulrush and American lotus were abundant. In 1936, 1937 and 1940, however, moist-soil plants-such as millets, smartweeds, nutgrasses and water hemp--were very abundant on the mud flats about certain lakes of this last class.

7. Floods which occur between June and September may be destructive to aquatic plants. A reduction in the abundance of sago pondweed, American lotus, duck potato and river bulrush is often directly traceable to high water. 
S. Drought may not only lower water levels sufficiently to enable desirable moist-soil herbaceous plants to develop on mud flats, but it may also be conducive to growth of huttonbush and willows, species of little or no value as sources of waterfowl food.

9. Turbidity is influenced by fluctuating water levels, wave action, fish, plants, soils and pollution.

10. A transparency of less than 9 inches. through the growing season, almost precludes development of submerged and Hoating aquatic plants.

11. Soils and sedimentation, wave action and commercial fishing are other factors influencing the development of aquatic plants.

12. The amount of seeds produced by certain duck food plants varies annually and with the habitat in which the plant grows. Moist-soil plants apparently produce more seeds per unit area than aquatic plants.

13. Rice cut-grass, coontail, marsh smartweed and longleaf pondweed were the hest duck food plants in the 1llinois River valley in 1938, when moist-soil plants were wanting. $\mathrm{W}$ ild and Japanese millets, pigweed, nutgrasses and nodding smartweed were among the top-ranking foods in 1939 and 1940.

14. American lotus, river bulrush, huttonbush and willow furnish little or no duck food, and are undesirable in many waterfowl feeding grounds, since they compete with more valuable duck food plants.

15. Present methods for control of aquatic and marsh weeds leave much to be desired. Natural, manual, mechanical and chemical methods may be employed. Flooding and cutting the weeds by hand or by a mechanical device appear to be the most practical methods.

16. Aquatic and marsh plants spread into newly created or altered habitats by: natural dispersal methods.

17. Only fair and temporary benefits have thus far resulted from thousands of dollars spent by duck clubs on waterfowl food plantings.

18. At least partial control of water levels through small dams and levees is necessary if duck clubs in certain areas are to achieve maximum results from waterfowl food planting programs.

19. Two desirable methods of managing waterfowl habitats in the Illinois River valley are as follows:

(a) Lower waters early in summer, exposing mud thats for development of moist-soil plants such as nutgrasses, pigweed, smartweeds, rice cut-grass, wild and Japanese millets. This method is, in general, suited to the area between Peoria and Browning.

(b) Maintain water level at depths of 2 to 3 feet for development of aquatic plants such as sago, longleaf and hushy pondweeds and coontail. This method is, in general, suited to the region between Henry and Peoria.

20. Where it is impossible to improve physical conditions, plantings should be made only of those species tolerant of fluctuating water levels and turbidity.

21. In certain years it is possible to take advantage of natural conditions to plant Japanese millet and chufa on mud Hats.

22. Aquatic and moist-soil plants generally appear naturally in areas when suitable environmental conditions occur.

23. Desirable duck food plants may be propagated from one or more of the following: tubers, rootstocks, winter huds, leafy cuttings, seeds and transplants of entire plants.

24. The most favorable planting time in the Illinois River valley is late May and early June.

25. Water-saturated aquatic plant seeds often sink in water; if they Hoat. they should be cmbedded in mud balls before being planted. In shallow water, tubers and rootstocks of aquatic plants may be planted directly in the bottom; in deep water, they should be embedded first in mud balls, which can then be dropped in the desired place.

26. Marsh plants usually thrive on moist soil, or in water not more than 18 inches deep. Aquatic plants do best in water 18 inches to $t$ feet in depth. Lack of transparency in water is a limiting factor in the depth to which aquatic plants will grow. 


\section{I T E R A T U R E C I T E D}

Bellrose, Frank C. 1938. Abundance and food habits of the waterfowl in the Illinois River valley. B. S. Thesis, Univ, of Ill. 33 pp.

Bellrose, Frank C., and Harry G. Anderson. 1940. Preliminary report on availability and use of waterfowl food plants in the Illinois River valley. IIl. Nat. Hist. Surv. Biol. Notes 15. $14 \mathrm{pp}$.

Martin, A. C., and F. M. Uhler. 1939. Food of game ducks in the United States and Canada. U.'S. Dept. Ag. Tech. Bul. 634.156 pp., illus.

McAtee, W. L. 1939. Wildfowl food plants. Collegiate Press, Inc., Ames, lowa. 141 pp., illus.

\section{A P P E N D I X}

\section{List of Waterfowl Food Plants in the Illinois River Valley}

The following is a list of all but the rarer plants occurring in the Illinois River valley that may be used as food by waterfowl. With few exceptions the classification and nomenclature follow Gray's New Manual of Botany, Seventh Edition.

Comman $\underset{\text { Names }}{\text { Vernacular }}$

Muskgrass

Giant bur-reed, burhead

Longleaf pondweed, deer's

tongue
Leafy pondweed

Small pondweed

Sago pondweed, teal grass, eel grass

Bushy pondweed, southern naiad

Water plantain

Arrowleaf, arrowhead

Duck potato, wapato, arrowhead, bootjack Stiff arrowhead, duck potate

Waterweed, elodea

Narrow-leaved waterweed

Wild celery, tape grass

Creeping eragrostis, love grass, teal grass

Common reed, cane

Wild rye

Marsh cord grass, slough grass, marsh hay

White grass

Rice cut-grass, saw grass

Catch-fly grass

Wild rice

Witchgrass

Switchgrass

Fall panicum, spreading switchgrass

Wild miller, harnyard grass, duck millet, corn grass, duck corn

Japanese millet, duck milJat

Walter's millet, corn grass. tall duck millet

Nutgrass, straw-colored cyperus, teal grass

Nutgrass, red-rooted cyperus, teal grass

Chufa, ground almond, nutgrass, teal grass

American bulrush, three-

square
Softstem bulrush, tule, roundstem bulrush

Hardstem bulrush, big bulrush, tule

River bulrush, flag, threesquare flay

Dark-green hulrush

\section{Scientific Names}

Chara spp.

Sparganium eurycarpum Engelm.

Potamageton americanus $\mathrm{C}$. $\& \mathrm{~S}$.

Polamageton faliosus Raf.

Patamogetan pusillus L.

Polamagetan pectinalus $\mathrm{L}$.

Najas guadalupensis

(Spreng.) Morong.

Alisma Plantago-aqualica

L.

Laphotacarpus calycinus

(Engelm.) J. G. Sm.

Sagillaria latifolia Willd.

Sagillaria cuneala Sheldon
Sagillaria rigida (Pursh) Engelm.

Anacharis conadensis

(Michx.) Planch.

Anachar is occidentalis (Pursh) Vict.

Vallisneria spiralis L.

Erogrostis hypnoides (Lam.) BSP.

Phragmiles communis Trin.

Elymus virginicus $\mathrm{L}$

Spartina Michauxiana Hitchc.

Leersia virginica Willd

Leersia oryzoides (L.) Sw.

Leersia lenticularis Michx.

Zizania aquatice $\mathrm{L}$.

Panicum copillare $\mathrm{L}$

Panicum Galtingeri Nash

Panicum virgatum $\mathrm{L}$.

Panicum dichotomiflorum Michx.

Echinachioa crusgalli (L.) Beauv.

Echinochloa frumentacea (Roxb.) Link Echinachloa Walieri (Pursh)
Nash

Cyperus sirigosus $\mathrm{L}$.

Cyperus erylhrarhizas Muhl.

Cyperus esculentus L.

Scirpus americanus Pers.

Scirpus validus Vahl.

Scirpus aculus Muhl.

Scirpus fuvialilis (Torr.) Gray
Scirpus alrovirens Muhl.
Blunt spike rush, wiregrass

Common spike rush, wiregrass

Arrow arum, wampee, duck corn

Greater duckweed, teal moss, seed moss, floating duck's meat

Submerged duckweed, star duckweed, star duck's meat

Lesser duckweed, teal moss, seed moss floating duck's meat

Minute duckweed

Watermea]

Pickerelweed

Mud plantain, water star-

grass
Tall dock, pale dock

Curly dock, yellow dock

Swamp dock

Nodding smartweed

Marsh smartweed, reci-top, shoestring, water smartweed

Largeseed smartweed

Water pepper

Dotted smartweed

Lady's thumb

Swamp smartweed, white water smartweed

Arrowleaf tearthumb

Water hemp pigweed, hogweed

Coontail, hornwort, foxtail

mose, water moss, moss

Yellow pond lily, spatterdock

White water lily. pond lily

American lotus, yawky, yorkey nut, yonkapin

White water buttercup

Water cress

Fox grape

Riverbank grape

Marsh mallow

Long-leaved ammannia

Water willow, swamp loosestrife

Creeping water primrose, floating primrose willow

Water milfoil

Swamp privet

Fog-fruit

Bladderwort

Buttonbush, buckbrush

Greater ragweed

Lesser ragweed

Western ragweed

Cocklebur

Spanish needles, beggarticks, pitchiork
Eleocharis abtusa (Willd. Schultes

leocharis palustris (L.) R. $\& \mathrm{~S}$.

Pellandra virginica (L.) Kunth

Spirodela polyrhiza (L.)

Schleid.

Lemna trisulsa L.

Lemna minar $L$.

Lemna minima Phillipi

Walffia columbiana Karst

IValffia punrtaia Griseb.

Pantederia cordala L

Heleranthera dubia (Jacq.) MacM.

Rumex allissimus Wood

Rumex crispus L.

Rumex verticillalus $\mathrm{L}$.

Polyganum la paihifolium $\mathrm{L}$.

Palyganum Muhlenbergii (Meisn.) Wats.

Polygonum pennsylvanicum L.

Palygonum Hydropiper L. Polyganum punclalum Ell.

Polyganum Persicaria L.

Polygonum hydrapiperaides Michx.

Polyganum sagiltalum $\mathrm{L}$.

Acnida tuberrulata Moq.

Ceratophyllum demersum $\mathrm{L}$

Nymphaea advena Ait.

Costalia tuberasa (Paine) Greene

Nelumbolutea (Willd.) Pers.

Ranunculus aquatilis L. var. capilloceus DC.

Radicula Nasturlizemaquaticum (L.) Britten \& Rendle

Vitis labrusca $\mathrm{L}$

Vilis vulpina $\mathrm{L}$.

Hibiscus militaris Cav.

Ammannia caccinea Rotth.

Decadon verticillatus (L.) Ell.

Jussigea diffusa Forsk.

Myriaphyllum spp.

Forestiera acuminalo (Michx.) Poir.

Lippia lanceolato Michx.

Utricularia spp.

Cephalanthus occidentalis $\mathrm{L}$

A mbrasia lrifida $\mathrm{L}$

A mbrasia arlemisiifolia $\mathrm{L}$

A mbrasia psilastachya DC.

Xanthium spp.

Bidens cernua L.

Bidens comasa (Gray Wiegand

Bidens trichosperme

(Michx.) Britton

Bidens frondoso $\mathrm{L}$. 



\section{Recent Publications \\ of the Illinois Natural History Survey}

A.-ILLINOIS NATURAL HISTORY SURVEY BULLETIN.

Volume 21, Article 3.-Studies of Nearctic Aquatic Insects. By H. H. Ross and T. H. Frison. September, 1937. 52 pp., frontis. +86 figs., bibliog. 50 cents.

Contents: 1. Nearctic alder fles of the genus Sialis (Megalopters, Sialidee), by H. H. Ross; and

11. Descriptiona of Plecoptera, with special reference to the lliinois apecles. by T. H. Frikon.

Volume 21, Article 4.-Descriptions of Nearctic Caddis Flies (Trichoptera), with special reference to the Illinois species. By Herbert H. Ross. March, 1938. 84 pp., frontis. + 123 figs., foreword, index. $\$ 1.00$.

Volume 21, Article 5.--Preliminary Studies on Parasites of Upland Game Birds and Fur-Bearing Mammals in Illinois. By W. Henry Leigh. August, 1940. 10 pp., frontis. +2 maps.

Volume 21, Article 6.-Preliminary investigation of oak diseases in Illinois. By J. Cedric Carter. June, 1941. 36 pp., frontis. + 51 figs., bibliog. (Bound with Article 7.)

Contenta: Review of literature; Methods of study; incldence of oak diseases: Canker and dieback diseases; Canker diseases; Dieback discases, Root rot; Miscellaneous fungi.

Volume 21, Article 7.-A needle blight of Austrian pine. By Robert L. Hulbary. June, 1941. 6 pp., frontis. +3 figs., bibliog. (Bound with Article 6.)

B.-ILLINOIS NATURAL HISTORY SURVEY CIRCULAR.

32.-Pleasure With Plants. By L. R. Tehon. April, 1939. 32 pp., frontis. +9 figs.

Contents: What is botsnizlng? Ways to botanize; Where to botanize; When to botanize; How to hotanize; Studylng plants; Equipment for studying plsnts; The herbarium; Useful books; Ma pa; Concluaion.

33.-Controlling Peach Insects in Illinois. By S. C. Cbandler and W. P. Flint. August, 1939. 40 pp., frontis. +32 figs.

Contenta: Part I. Ingecta attacking bark end trunk of the peach tree-San Jose seale, peach horer, leaser peach borer, ghot-hole borer and peach bark beetle, terrapin acale; Part Il. Ingecta attacking twigg, foliage and fruit of the peach tree-orlental fruit moth, peach twlg borer, plum curculio, tarnished plant bug, atink bugs, Japanese beetle, green June beetle, cotton leaf worm moth, aphiảs, grasshoppers, tree cricket, perlodical cicada, thrips.

34.-Rout the Weeds! Why, When and How. By L. R. Tehon. January, 1940. (Second printing.) 47 pp., color frontis. + 13 figs.

Contents:- The importance of weeds; Weeds as economic factors; Weeds as harborers of inaecta ; Weeds as harborers of plsnt diseases; Relation of weeds to public health; Control methoda : Thirteen noxious and pernicious weeds of Illinois-European bindweed, perennial aow thistle, Canada thistle, common ragweed, weatern ragweed, lance-leaved ragweed, giant ragweed, poison ivy, polaon sumac, wild parsnip, white auakeroot, pokeweed, common burdock.

35.-Diseases of Small Grain Crops in Illinois. By G. H. Boewe. September, 1939. 130 pp., frontis. +47 figs.

Contents: Nsture of cereal diseases; Wheat diseases; Oats diseases; Barley diseases; Ryo

37.-Outwitting Termites in Illinois. By W. E. McCauley and W. P. Flint. April, 1940. 23 pp., frontis. +19 figs.

Contents: Termites and their habita; Structural control of termites; Control of termiteg with chemicala; Unlfied action agalnat termites.

38.-Windbreaks for Illinois Farmsteads. By J. E. Davis, December, 1940. 24 pp., frontis. +19 figs.

Contenta: Introduction; Planning the windbreak; Plenting the windbreak; Care of the wlndbreak; What the windbreak treea are like.

39.-How to Collect and Preserve Insects. By H. H. Ross. June, 1941. 48 pp., frontis. +53 figs.

Tontents: Where to collect; What to use: Special collecting equipment: Sending insects for identification; How to handie unmounteo apecimena; How to mount and preaerve apecimens; How to label the specimens; Houaing the collection permanently; Identifylng the specimeng; Uaeful books; How to ahip a collectlon; Where to buy gupplies.

C.-ILLINOIS NATURAL HISTORY SURVEY MANUAL.

1.-Fieldbook of Illinois Wild Flowers. By the staff. March, 1936. 406 pp., color frontis. + 349 figs., index. $\$ 1.50$.

Contenta: Introduction; Key to familes; Description of species $(650)$.

2.-Fieldbook of Illinois Land Snails. By Frank Collins Baker. August, 1939. 166 pp. color frontis. +170 figs., 8 pls. $\$ 1.00$.

Contents: Land snaila, what they are and where they live; Land snaila native to Iulnoia; Land enails introduced from foreign countries; Land snalig of uncertain presence in Iilinoin: Bibliography; Check list of Illinols species; Index.

Ilst af available publications, over 300 titles, mailed on request.

Address orders and correspondence to the Chief

ILLINOIS NATURAL HISTORY SURVEY

Natural Resources Building, Urbana, Illinois

Payment in the form of 0 . S. Post Office mones order made ont to State Treasurer of Iullnols, springfield, Illinols,

muat aocompany requests for those publications on which a prlce $1 \mathrm{~s}$ set. 